\title{
O IDOSO VÍTIMA DE ALIENAÇÃO PARENTAL: A APLICAÇÃO ANÁLOGA DA LEI 12.318 DE 2010
}

\author{
Vitória Salazar Souza* \\ Patrícia Outeiral de Oliveira***
}

\section{INTRODUÇÃO}

A alienação parental é prática encontrada nas relações familiares, merecendo extremo cuidado no que tange a sua identificação e aplicação das normas referentes ao tema. A Lei no 12.318 de 2010 trouxe regramento jurídico específico para esta realidade; entretanto, não tratou de amparar todas as possíveis vítimas deste fenômeno psicojurídico.

Delimita a referida lei que a vítima da alienação parental é a criança e o adolescente, quando sofre abuso pelo pai, mãe, avô, avó, guardião, ou ainda qualquer pessoa de seu círculo de afinidade. Todavia, a alienação parental não ocorre somente com a criança e o adolescente. Observa-se com frequência o afastamento dos idosos dos demais parentes e amigos. Esta ruptura dos vínculos de convivência geralmente é ocasionada pela influência de pessoas responsáveis pelo idoso, como os filhos ou curadores. ${ }^{1}$

\footnotetext{
* Graduanda do Curso de Direito da Faculdade Cenecista de Osório.

** Mestre em Direito. Coordenadora do Curso de Direito do Centro Universitário Metodista IPA

1 PODER JUDICIÁRIO DO ESTADO DO MATO GROSSO. Cartilha Alienação Parental. Disponível em:<hhttp://www.tjmt.jus.br/intranet.arq/downloads/ Imprensa/NoticiaImprensa/file/2014/04\%20-\%20Abril/25\%20-\%20Cartilha\%20-\%20Aliena\%C3\%A7\%C3\%A3o.pdf >. Acesso em: 15 ago. 2015.
} 
A alienação parental, normalmente, ocorre após a ruptura de um vínculo, seja do fim do casamento, da união estável ou pela morte. Dessa forma, a pessoa que se torna responsável pelo idoso pode ter dificuldades de suportar uma ruptura, sendo o idoso submetido a atitudes abusivas por parte do cuidador.

É possível a existência de casos onde o idoso se encontra na figura de vítima, sendo induzido a não se relacionar com determinadas pessoas que figuram em seu polo afetivo ou consanguíneo. Para tanto, o Estado não pode ficar omisso a essa realidade, sendo seu dever conhecer destarealidade social e sanar os litígios dela provenientes. 0 auxílio de estudos psicológicos e sociais se tornam necessários, a fim de assegurar os direitos intrínsecos ao idoso, posto sua condição vulnerável frente à sociedade em que se insere.

Neste diapasão, cinge-se a problemática da possibilidade ou impossibilidade de aplicação análoga da Lei 12.318 de 2010 ao idoso, discutindo se o idoso pode ser vítima de Alienação Parental.

Objetiva-se com este estudo demonstrar a fragilidade da pessoa idosa, sob análise da legislação vigente e da doutrina atual e a possibilidade de aplicação de modo análogo da lei 12.318 de 2010 para a proteção do direito a convivência familiar do idoso. Busca-se, da mesma forma, detectar os efeitos legais deste reconhecimento jurídico.

Desse modo, apresentar-se-á o tema em questão em dois capítulos. No primeiro, serão abordados os direitos previstos à pessoa idosa, trazendo conceituações básicas e como os direitos do idoso são previstos na Constituição Federal vigente e legislação infraconstitucional. No segundo tópico, analisar-se-á a Lei 12.318 de 2010 e a possibilidade de aplicação análoga da mesma frente ao estudo da vulnerabilidade da pessoa idosa e suas possíveis decorrências. 


\section{OS DIREITOS ASSEGURADOS AO IDOSO}

No cenário atual, o idoso tem papel bastante amplo e significativo. A qualidade de vida estáprofundamente relacionada ao bemestar físico e moral daqueles que estão acima dos 60 anos. A expectativa de vida tem aumentado, sendo necessário ampliar a compreensão das normas jurídicas com o fito de amparar esta realidade. Os idosos aos poucos foram sendo inseridos no âmbito jurídico, tendo seus direitos assegurados ${ }^{2}$.

A tutela ao idoso baseia-se nos preceitos contidos na Carta Magna de 1988, sendo princípios norteadores de todo o ordenamento jurídico, o da dignidade humana ${ }^{3}$, o da igualdade ${ }^{4}$ e o da liberdade ${ }^{5}$, sendo um dos objetivos fundamentais da nação a construção de uma sociedade livre, justa e solidária ${ }^{6}$. Além disso,

2 Em especial contidos na Constituição Federal de 1988 no art. 229 e Lei $10741 / 03$.

3 Art. 1ํ A República Federativa do Brasil, formada pela união indissolúvel dos Estados e Municípios e do Distrito Federal, constitui-se em Estado Democrático de Direito e tem como fundamentos: III - a dignidade da pessoa humana; BRASIL. Constituição da República Federativa do Brasil de 1988. Disponível em: <http://www.planalto.gov.br/ccivil_03/constituicao/ConstituicaoCompilado.htm>.http://www.planalto.gov.br/ccivil_03/constituicao/ ConstituicaoCompilado.htm Acesso em: 11 out. 2015.

4 Art. 5o Todos são iguais perante a lei, sem distinção de qualquer natureza, garantindo-se aos brasileiros e aos estrangeiros residentes no País a inviolabilidade do direito à vida, à liberdade, à igualdade, à segurança e à propriedade, nos termos seguintes: BRASIL. Constituição da República Federativa do Brasil de 1988. Disponível em: <http://www.planalto.gov.br/ccivil_03/constituicao/ConstituicaoCompilado.htm>. http://www.planalto.gov.br/ccivil_03/ constituicao/ConstituicaoCompilado.htm Acesso em: 11 out. 2015.

5 Art. 5o VIII - ninguém será privado de direitos por motivo de crença religiosa ou de convicção filosófica ou política, salvo se as invocar para eximir-se de obrigação legal a todos imposta e recusar-se a cumprir prestação alternativa, fixada em lei; BRASIL. Constituição da República Federativa do Brasil de 1988. Disponível em: http://www.planalto.gov.br/ccivil_03/constituicao/ ConstituicaoCompilado.htm<http://www.planalto.gov.br/ccivil_03/constituicao/ConstituicaoCompilado.htm> Acesso em: 11 out. 2015.

6 Art. 3ํㅡㄹ Constituem objetivos fundamentais da República Federativa do Brasil:I - construir uma sociedade livre, justa e solidária; BRASIL. Constituição da República Federativa do Brasil de 1988. Disponível em: <http://www. planalto.gov.br/ccivil_03/constituicao/ConstituicaoCompilado.htm>.http:// www.planalto.gov.br/ccivil_03/constituicao/ConstituicaoCompilado.htm Acesso em: 11 out. 2015. 
a Constituição Federal vigente traz no Capitulo VIII do Título VIII de seu texto os direitos da família, da criança, do adolescente, do jovem e do idoso, sendo impossível não associar a todos a proteção integral aos seus direitos.

\subsection{O IDOSO: HISTÓRICO E CONCEITUAÇÕES INICIAIS}

O termo idoso, de origem latina, deriva da palavra aetas que significa idade, combinada com o sufixo "oso", que norteia abundância ${ }^{7}$. Desta forma, o idoso pode ser entendido como uma pessoa de bastante idade. Entretanto, delimitar a idade em que a pessoa se torna idosa demanda uma série de reflexões, sob o ponto de vista físico, biológico e social.

As denominações "velho" e "idoso" afetam todos os indivíduos, tendo em vista que todos, naturalmente, são atingidos pela velhice. No entanto, a maneira será variável em relação ao tempo e ao espaço distintos. Sendo assim, a palavra "velho" é utilizada de forma depreciativa, considerando apenas a consequente falta de sentidos e perda do vigor para a vida ativa. Esta diminuição da vitalidade orgânica, todavia, é relativa, mostrando-se que há idosos em pleno vigor e outros afetados de forma visível pelo avanço da idade ${ }^{8}$.

Configura especial complexidade a delimitação da idade em que a pessoa se torna idosa, em que pese o envelhecimento ser um desenvolvimento de fatores biológicos, psíquicos e sociais. Portanto, a progressividade das fases do envelhecimento tem caráter subjetivo, uma vez que cada fator atua de uma forma, sendo dificultoso afirmar o início da velhice9.

VILAS BOAS, Marco Antônio. Estatuto do idoso comentado. 5. ed. Rio de Janeiro: Forense, 2015, p. 1.

8 VILAS BOAS, Marco Antônio. Estatuto do idoso comentado. 5. ed. Rio de Janeiro: Forense, 2015, p. 4.

9 SILVA, Nilson Tadeu Reis Campos. Direito do Idoso: tutela jurídica constitucional. Curitiba: Juruá, 2012, p. 27. 
Importa diferenciar dois fatores inerentes à forma da vida idosa: a senilidade e a senescência, que refletem significativamente na forma com que a sociedade se relacionará com o idoso. A primeira trata do envelhecimento de forma natural, que não necessariamente é acompanhado de patologias, tendo como característica uma vida ativa, no entanto, com restrições oriundas de distúrbios funcionais. A senescência, por sua vez, sobrevém de uma incapacidade progressiva para a vida ativa, desta forma, as doenças limitam o envelhecimento, alterando de forma expressiva as funcionalidades da pessoa ${ }^{10}$.

De acordo com o art. $2^{\circ}$ da Lei $8.842 / 94^{11}$ e $1^{\circ}$ da Lei $10.741 / 03^{12}$, idoso é aquele que possui 60 anos ou mais. Este critério segue os padrões da Organização Mundial de Saúde, que orienta aos países em desenvolvimento a estabelecer a idade de 60 anos para o ancião, e 65 anos para os países desenvolvidos, o que não é o caso do Brasil ${ }^{13}$.

Para a determinação da idade, utilizou-se o critério objetivo cronológico, partindo-se da premissa geral de que o envelhecimento biológico ocorre quando o indivíduo alcança 60 anos. Para

10 SILVA, Nilson Tadeu Reis Campos. Direito do Idoso: tutela jurídica constitucional. Curitiba: Juruá, 2012. p.28.

11 Art. 2ำ Considera-se idoso, para os efeitos desta lei, a pessoa maior de sessenta anos de idade. BRASIL. Lei 8842 de 4de janeiro de 1994. Disponível em: <http://www.planalto.gov.br/ccivil_03/leis/L8842.htm>http://www. planalto.gov.br/ccivil_03/leis/L8842.htm Acesso em 11 out. 2015.

12 Art. $1^{\circ}$ É instituído o Estatuto do Idoso, destinado a regular os direitos assegurados às pessoas com idade igual ou superior a 60 (sessenta) anos. BRASIL. Lei 10.741 de $1^{\mathrm{o}}$ de outubro de 2003. Estatuto do Idoso. Disponível em:<http://www.planalto.gov.br/ccivil_03/leis/2003/L10.741.htm>. http://www.planalto.gov.br/ccivil_03/leis/2003/L10.741.htm Acesso em: 11 out. 2015.

13 BALDONI, A.O.; PEREIRA, L.R.L. 0 impacto do envelhecimento populacional brasileiro para o sistema de saúde sob a óptica da farmacoepidemologia: uma revisão narrativa. Disponível em: <http://www.unifal-mg. edu.br/cefal/sites/default/files/Baldoni,\%20Pereira,\%202011.pdf>.http:// www.unifal-mg.edu.br/cefal/sites/default/files/Baldoni,\%20Pereira,\%20 2011.pdfAcesso em: 11 out. 2015. 
tanto, a velhice normalmente é configurada pela senilidade, na qual a pessoa perde parte de sua capacidade física naturalmente. 0 fator social também opera para esta classificação, posto as diferentes formações culturais existentes, que têm relação estrita com os fatores biológicos. Sendo assim, a linha tênue que separa o idoso dos demais sujeitos deve ser amplamente discutida, de acordo com o objetivo da política ou legislação a ser construída ${ }^{14}$.

As constituições brasileiras anteriores à de 1988 não recepcionaram a proteção ao idoso. Os investimentos em políticas públicas de combate à violência, à desigualdade social, à marginalização e à pobreza eram insatisfatórios. Da mesma forma, não se destinava verbas para saneamento básico, educação, saúde preventiva ou habitação, deixando os direitos humanos fundamentais sem efetivação $0^{15}$.

O idoso, nas constituições passadas, era mencionado apenas com respeito aosdireitos trabalhistas, prevendo seguro social àqueles trabalhadores que não mais conseguissem realizar seu trabalho, mediante contribuição prévia. Na década de 1970, os idosos começaram a associar-se e organizar-se na luta de seus direitos ${ }^{16}$.

A transição para a democracia abarcou diversos avanços no que tange aos direitos sociais. A Carta de 1988 inovou ao trazer o idoso como sujeito de direitos constitucionais, reconhecendo

14 CAMARANO, Ana Amélia. et al. Como vai o idoso brasileiro. Disponível em: <http://repositorio.ipea.gov.br/bitstream/11058/2810/1/td_0681. pdf>.http://www.ipea.gov.br/portal/images/stories/PDFs/TDs/td_0681.pdf Acesso em: 11 out. 2015.

15 RAMOS, Paulo Roberto Barbosa. Avelhice na constituição. Disponível em: <https://periodicos.ufsc.br/index.php/sequencia/article/download/15513/14069>https://periodicos.ufsc.br/index.php/sequencia/article/ viewFile/15513/14069. Acesso em: 11 out. 2015.

16 FALEIROS, Vicente de Paula. Cidadania e direitos da pessoa idosa. Disponível em: <http://repositorio.unb.br/bitstream/10482/8353/1/ ARTIGO_CidadaniaDireitosPessoaIdosa.pdf>. http://repositorio.unb.br/bitstream/10482/8353/1/ARTIGO_CidadaniaDireitosPessoaIdosa.pdf Acesso em: 11 out. 2015. 
um amplo rol dos direitos fundamentais ${ }^{17}$. Dessa forma, a fundamentalidade da dignidade da pessoa humana aliada ao direito à vida garante ao idoso o direito fundamental ao envelhecimento ${ }^{18}$. Além de garantias universais como de igualdade, dignidade e solidariedade, destina a CF 1988 o Capítulo VII do Título VIII à proteção da família, da criança, do jovem e do idoso. 0 art. 230 da Magna Carta obriga a família, a sociedade e o Estado a amparar o idoso, garantindo-lhe o direito à vida digna ${ }^{19}$.

0 crescimento da população idosa mundial é exorbitante. Estima-se que em 2050 esta faixa etária superará a de crianças até 15 anos. No Brasil, o número de idosos dobrou nas últimas duas décadas, em detrimento do número de nascimentos, que diminui significativamente. Diante desta realidade, o país observou a obrigatoriedade de adequações sociais para suprir as necessidades dos anciãos, como a garantia de direitos, acesso à segurança, informação, mobilidade, segurança e saúde preventiva ${ }^{20}$.

17 Art. 5o Todos são iguais perante a lei, sem distinção de qualquer natureza, garantindo-se aos brasileiros e aos estrangeiros residentes no País a inviolabilidade do direito à vida, à liberdade, à igualdade, à segurança e à propriedade, nos termos seguintes: BRASIL. Constituição da República Federativa do Brasil de 1988. Disponível em: <http://www.planalto.gov.br/ccivil_03/constituicao/ConstituicaoCompilado.htm>. http://www.planalto.gov.br/ccivil_03/ constituicao/ConstituicaoCompilado.htmAcesso em: 11 out. 2015.

18 RAMOS, Paulo Roberto Barbosa. Avelhice na constituição. Disponível em: <https://periodicos.ufsc.br/index.php/sequencia/article/download/15513/14069>.https://periodicos.ufsc.br/index.php/sequencia/article/ viewFile/15513/14069 Acesso em: 11 out. 2015.

19 Art. 230. A família, a sociedade e o Estado têm o dever de amparar as pessoas idosas, assegurando sua participação na comunidade, defendendo sua dignidade e bem-estar e garantindo-lhes o direito à vida. $\S 1^{0}$ Os programas de amparo aos idosos serão executados preferencialmente em seus lares. $\S$ $2^{\circ}$ Aos maiores de sessenta e cinco anos é garantida a gratuidade dos transportes coletivos urbanos. BRASIL. Constituição da República Federativa do Brasil de 1988. Disponível em: <http://www.planalto.gov.br/ccivil_03/ constituicao/ConstituicaoCompilado.htm>.http://www.planalto.gov.br/ccivil_03/constituicao/ConstituicaoCompilado.htm Acesso em: 11 out. 2015.

20 BRASIL. Presidência da República: Secretaria de Direitos Humanos. Dados sobre o envelhecimento no Brasil. Disponível em: <http://www.sdh.gov.br/ 
Apesar da contribuição inigualável da população idosa para a identidade da nação, ainda predomina o preconceito e a discriminação em relação a essas pessoas, tendo em vista suas limitações físicas e mentais advindas da idade elevada. Contudo, a difusão de valores sociais que consideram o idoso fundamental à construção da sociedade, garantindo a estes a efetivação de seus direitos, tendo como fim o respeito à vida desde o nascimento até a morte, em toda sua plenitude ${ }^{21}$.

\subsection{O IDOSO NAS CONSTITUIÇÕES}

A problemática social da velhice não era considerada relevante até a Constituição de 1988, demonstrando o atraso social do Brasil frente à efetivação dos direitos humanos. Conforme as estimativas da Organização das Nações Unidas ${ }^{22}$ o Brasil sempre esteve entre os últimos colocados na avaliação do Índice de Desenvolvimento Humano; dentre os fatores desta derradeira posição está a falta de investimento na erradicação da pobreza, da marginalização, da violência e na ausência de políticas públicas direcionadas ao saneamento básico, qualidade de vida, saúde e habitação ${ }^{23}$.

Antes de 1934, não havia previsão sobre os direitos específicos do idoso, bastando à Constituição de 1891 propiciar

assuntos/pessoa-idosa/dados-estatisticos/DadossobreoenvelhecimentonoBrasil.pdf>.http://www.sdh.gov.br/assuntos/pessoa-idosa/dados-estatisticos/ DadossobreoenvelhecimentonoBrasil.pdf Acesso em 11 out. 2015.

21 KEINERT, Tania Margarete Mezzamo; ROSA, Tereza Etsuko da Costa. Direitos humanos, envelhecimento ativo e saúde da pessoa idosa: marco legal e institucional. Disponível em: http://periodicos.ses.sp.bvs.br/scielo. php?script=sci_arttext\&pid=S1518=18122009000200002-\&lng $=$ pt $\&$ nrmis o <http://periodicos.ses.sp.bvs.br/scielo.php?script=sci_arttext\&pi$\mathrm{d}=\mathrm{S} 1518-18122009000200002 \& \operatorname{lng}=$ pt\&nrm=iso $>$. Acesso em 11 out. 2015.

22 De acordo com a última avaliação do Índice de Desenvolvimento Humano, o Brasil tem 79a posição. PROGRAMA DAS NAÇÕES UNIDAS PARA O DESENVOLVIMENTO. Índice de desenvolvimento humano 2013. Disponível em: <http://www.pnud.org.br/arquivos/rdh-2013.pdf>.http://www.pnud.org. br/atlas/ranking/Ranking-IDH-Global-2013.aspxAcesso em: 11 out. 2015.

23 RAMOS, Paulo Roberto Barbosa. Curso de Direito do Idoso. São Paulo: Saraiva, 2014. p. 97. 
aposentadoria aos velhos inválidos e aos magistrados com mais de 30 anos de trabalho. A Constituição Federal de 1934 inovou a trazer à previdência social o direito de aposentadoria aos velhos, mediante contribuição do trabalhador, da União e do empregador; contudo, não proporcionou à velhice digna caráter de direito, limitando uma classe de trabalhadores à uma mísera aposentadoria. As constituições posteriores (1937, 1946, 1967 e 1969) em nada alteraram estes dispositivos ${ }^{24}$.

A Carta de 1988 foi a primeira a elencar direitos fundamentais à pessoa humana, admitindo como fundamento da República a dignidade humana ${ }^{25}$.

Toda Constituição tem como objetivo direcionar as principais concepções da nação, as quais todo o ordenamento jurídico deve se submeter. Para tanto, os direitos fundamentais nela previstos norteiam todo e qualquer julgamento.

Para J.J. Gomes Canotilho:

A constitucionalização tem como consequência mais notória a proteção dos direitos fundamentais mediante o controlo jurisdicional da constitucionalidade dos actos normativos reguladores destes direitos. Por isso e para isso, os direitos fundamentais devem ser compreendidos, interpretados e aplicados como normas jurídicas vinculativas e não como trechos ostentatórios ao jeito das grandes "declarações de direitos"26.

24 RAMOS, Paulo Roberto Barbosa. Curso de Direito do Idoso. São Paulo: Saraiva, 2014. p. 97-101.

25 Art. 1o A República Federativa do Brasil, formada pela união indissolúvel dos Estados e Municípios e do Distrito Federal, constitui-se em Estado Democrático de Direito e tem como fundamentos: III - a dignidade da pessoa humana; BRASIL. Constituição da República Federativa do Brasil de 1988. Disponível em: <http://www.planalto.gov.br/ccivil_03/constituicao/ ConstituicaoCompilado.htm>. Acesso em: 11 out. 2015.

${ }^{26}$ CANOTILHO, José Joaquim Gomes. Direito constitucional e teoria da constituição. 7. ed. Coimbra: Almedina, 2003. p. 378. 
Desta percepção, compreende-se a importância da constitucionalização dos direitos fundamentais para a eficácia de todo o ordenamento jurídico, tendo em vista que a Constituição serve de pilar ao reconhecimento dos direitos em todas as suas áreas.

Como direito fundamental, o direito à vida se estendeà continuidade desta, contando com proteção à sua dignidade, refletindo em uma concepção em que o ser humano é respeitado em todas as fases da vida. A velhice, portanto, configura um direito humano fundamental, pois é a extensão do direito à vida e se liga à dignidade da pessoa humana ${ }^{27}$. Decorrente das reivindicações sociais e dos direitos de fraternidade e solidariedade, observa-se, da mesma forma, a qualidade de vida como direito fundamental, devendo o idoso contar com tal garantia ${ }^{28}$.

Os direitos fundamentais estão previstos no art. 5ำ da CF; entretanto, trata-se de rol exemplificativo, existindo outros direitos fundamentais espalhados pela Carta Magna. Desse modo, faz-se necessário a conceituação de direitos fundamentais, termo que gera discussões doutrinárias e que pode ser confundido com expressões como direitos humanos, direitos do homem, direitos individuais, direitos subjetivos públicos. Direitos fundamentais é a terminologia adotada pela atual constituição e engloba as demais divisões destes direitos destinados à pessoa humana ${ }^{29}$.

27 RAMOS, Paulo Roberto Barbosa. A velhice na constituição. Disponível em: <https://periodicos.ufsc.br/index.php/sequencia/article/download/15513/14069>https://periodicos.ufsc.br/index.php/sequencia/article/ viewFile/15513/14069. Acesso em: 11 out. 2015.

280 direito fundamental à velhice insculpe-se nos chamados direitos de terceira dimensão. Nesta senda: "A nota distintiva destes diretos da terceira dimensão reside basicamente na sua titularidade transindividual (ou metaindividual), muitas vezes indefinida e indeterminável, o que se revela, a título de exemplo, especialmente no direito ao meio ambiente e qualidade de vida, o qual, em que pese ficar preservada sua dimensão individual, reclama novas técnicas de garantia e proteção". SARLET, Ingo Wolfgang; MARINONI, Lui Guilherme; MITIDIERO, Daniel. Curso de direito constitucional. 3. ed. São Paulo: Editora Revista dos Tribunais, 2014.

29 SARLET, Ingo Wolgang. A eficácia dos direitos fundamentais: uma teoria geral dos direitos fundamentais na perspectiva constitucional. 10. ed. Porto Alegre: Livraria do Advogado, 2010, p. 27. 
A concepção de direitos humanos fundamentais vai além do entendimento de que tratam de direitos positivados expressa ou implicitamente na ConstituiçãoFederal, assegurados pela ordem jurídico-constitucional ${ }^{30}$. Mais do que instrumentos de defesa da liberdade individual, os direitos fundamentais atuam como fundamento da ordem jurídica existente, integrando o sistema de normas ${ }^{31}$.

A titularidade dos direitos fundamentais tem perspectiva subjetiva na ordem dos direitos fundamentais, sendo o sujeito ativo desta relação, desta forma, o titular, que se caracteriza por ser aquele afetado pelo direito fundamental. De outra banda, o destinatário dos direitos fundamentais é a pessoa física, jurídica ou ente despersonalizado, qual o titular pode exigir respeito e proteção, a fim de efetivar seu direito ${ }^{32}$.

A Constituição de 1988 prestou especial proteção ao idoso, fruto da reivindicação e organização desta faixa etária em busca do reconhecimento de seus direitos. Sendo assim, a Constituição Federal vigente tratou da vida como umdireito fundamental, sendo a velhice uma das fases de desenvolvimento da vida humana ${ }^{33}$.

Depreende-se da Constituição Federal os princípios norteadores do ordenamento jurídico vigente, como a igualdade, a

30 SARLET, Ingo Wolfgang. 0 conceito de direitos fundamentais na constituição federal de 1988. Disponível em: <http://www.conjur.com. br/2015-fev-27/direitos-fundamentais-conceito-direitos-fundamentaisconstituicao-federal-1988>.http://www.conjur.com.br/2015-fev-27/direitos-fundamentais-conceito-direitos-fundamentais-constituicao-federal-1988 Acesso em: 11 de out. 2015.

31 SARLET, Ingo Wolgang. A eficácia dos direitos fundamentais: uma teoria geral dos direitos fundamentais na perspectiva constitucional. 10. ed. Porto Alegre: Livraria do Advogado, 2010, p.60.

32 SARLET, Ingo Wolgang. A eficácia dos direitos fundamentais: uma teoria geral dos direitos fundamentais na perspectiva constitucional. 10. ed. Porto Alegre: Livraria do Advogado, 2010. p. 208.

33 RAMOS, Paulo Roberto Barbosa. A velhice na constituição. Disponível em: https://periodicos.ufsc.br/index.php/sequencia/article/viewFile/15513/14069<https://periodicos.ufsc.br/index.php/sequencia/article/ download/15513/14069>. Acesso em: 11 out. 2015. 
liberdade e o direito à vida. Os direitos fundamentais contidos em nossa Constituição decorrem do princípio fundamental da dignidade da pessoa humana, concretizando-o ${ }^{34}$.

A Carta de 1988 foi a primeira Constituição brasileira a trazer em seu texto a proibição da discriminação por idade, além de raça, cor, sexo, origem ${ }^{35}$. Esta coibição atinge em especial os idosos, que por vezes sofrem preconceito pela idade elevada e as peculiaridades advindas desta. Não obstante, outros dispositivos constitucionais foram destinados à proteção do idoso, como o art. 5 da Constituição Federal ${ }^{36}$.

Do mesmo modo, a Constituição de 1988 destinou à família, à criança, ao jovem e ao idoso um capítulo exclusivo. Os artigos. $229^{37}$ e $230^{38}$ da CF especificam diretamente a proteção à velhice, trazendo como obrigatória a assistência pela família, sociedade

34 FARIAS, E. Pereira de. Colisão de direitos: a honra, a intimidade, a vida privada e a imagem versus a liberdade de expressão e informação.Porto alegre: Fabris, 1996. p.54-5 apud SARLET, Ingo Wolgang. A eficácia dos direitos fundamentais: uma teoria geral dos direitos fundamentais na perspectiva constitucional. 10. ed. Porto Alegre: Livraria do Advogado, 2010, p.70.

35 Art. 5o XLI - a lei punirá qualquer discriminação atentatória dos direitos e liberdades fundamentais; BRASIL. Constituição da República Federativa do Brasil de 1988. Disponível em: <http://www.planalto.gov.br/ccivil_03/ constituicao/ConstituicaoCompilado.htm>.http://www.planalto.gov.br/ccivil_03/constituicao/ConstituicaoCompilado.htm Acesso em: 11 out. 2015.

36 RAMOS, Paulo Roberto Barbosa. Curso de Direito do Idoso. São Paulo: Saraiva, 2014, p.111.

37 Art. 229. Os pais têm o dever de assistir, criar e educar os filhos menores, e os filhos maiores têm o dever de ajudar e amparar os pais na velhice, carência ou enfermidade. BRASIL. Constituição da República Federativa do Brasil de 1988. Disponível em: <http://www.planalto.gov.br/ccivil_03/ constituicao/ConstituicaoCompilado.htm>.http://www.planalto.gov.br/ccivil_03/constituicao/ConstituicaoCompilado.htm Acesso em: 11 out. 2015.

38 Art. 230. § 1응 Os programas de amparo aos idosos serão executados preferencialmente em seus lares. $§ 2^{\circ}$ Aos maiores de sessenta e cinco anos é garantida a gratuidade dos transportes coletivos urbanos. BRASIL. Constituição da República Federativa do Brasil de 1988. Disponível em: <http:// www.planalto.gov.br/ccivil_03/constituicao/ConstituicaoCompilado.htm>. http://www.planalto.gov.br/ccivil_03/constituicao/ConstituicaoCompilado. htm Acesso em: 11 out. 2015. 
e Estado, garantindo-lhes uma vida digna, seu bem-estar e sua inserção na comunidade ${ }^{39}$.

0 art. $229^{40}$ da ConstituiçãoFederal prevê a obrigação recíproca de assistência e amparo dos pais e filhos, dessa forma, os filhos têm o dever de cuidado para com os pais a velhice, carência ou enfermidade. Da mesma forma, o art. $230^{41}$ prediz:

Art. 230. A família, a sociedade e o Estado têm o dever de amparar as pessoas idosas, assegurando sua participação na comunidade, defendendo sua dignidade e bem-estar e garantindo-lhes o direito à vida. $\S 1^{\text {o }}$ Os programas de amparo aos idosos serão executados preferencialmente em seus lares.

$\S 2^{\circ}$ Aos maiores de sessenta e cinco anos é garantida a gratuidade dos transportes coletivos urbanos.

Depreende-se da análise desse artigo que o dever de zelo para com o idoso é previsão clara na Constituição, devendo esta percepção acompanhar qualquer interpretação infraconstitucional. 0 conjunto de obrigados formado pela família, pela sociedade e pelo Estado devem defender o bem-estar do maior de 60 anos, bem como garantir-lhe o direito à vida. 0 parágrafo primeiro do art. 230 preza pelo cuidado familiar, no lar, tratando do direito de convivência familiar.

39 RAMOS, Paulo Roberto Barbosa. Curso de direito do idoso. São Paulo: Saraiva, 2014. p. 111

40 Art. 229. Os pais têm o dever de assistir, criar e educar os filhos menores, e os filhos maiores têm o dever de ajudar e amparar os pais na velhice, carência ou enfermidade. BRASIL. Constituição da República Federativa do Brasil de 1988. Disponível em: < http://www.planalto.gov.br/ccivil_03/ constituicao/ConstituicaoCompilado.htm>.http://www.planalto.gov.br/ccivil_03/constituicao/ConstituicaoCompilado.htm Acesso em: 11 out. 2015.

41 BRASIL. Constituição da República Federativa do Brasil de 1988. Disponível em: <http://www.planalto.gov.br/ccivil_03/constituicao/ConstituicaoCompilado.htm>.http://www.planalto.gov.br/ccivil_03/constituicao/ ConstituicaoCompilado.htm Acesso em: 11 out. 2015. 


\subsection{O IDOSO NA LEGISLAÇÃO INFRACONSTITUCIONAL}

O idoso conta, além da proteção inovadora oriunda da Constituição Federal de 1988, com a legislação infraconstitucional, que auxilia na efetivação dos preceitos contidos na Carta Magna, aproximando a proteção do idoso à família, à sociedade e ao Estado.

Proveniente de longos debates, em 1994, surge a Política Nacional do Idoso. Fruto de seminários promovidos pela Associação Nacional de Gerontologia, fomentados pela movimentação internacional pela regularização dos direitos do idoso, em 1990 inicia-se o estudo construído por representantes de órgãos governamentais e não governamentais, que culminou em um plano provisório sobre o que posteriormente viria a ser a Política ${ }^{42}$.

Unidos esforços de conselhos e organizações atuantes no cenário, o texto do Decreto-Lei que instituiu a Política finalmente foi redigido, sendo promulgado em 1994 a Lei no 8.842, que também incluía o intuito de implantar o Conselho Nacional do Idoso; contudo, o então Presidente vetou sua criação ${ }^{43}$.

A Lei 8.842/94 trata da Política Nacional do Idoso, que consiste em uma série de dispositivos com o objetivo de promover ao idoso sua autonomia, integração e participação efetiva na sociedade $^{44}$. Dessa forma, seguindo os padrões da Organização Mundial de Saúde, definiu o idoso como aquele tendo 60 anos ou mais ${ }^{45}$.

42 RODRIGUES, Nara da Costa. Política nacional do idoso: retrospectiva histórica. Disponível em: <http://www.seer.ufrgs.br/RevEnvelhecer/article/ viewFile/4676/2593>. Acesso em: 25 out. 2015.

43 RODRIGUES, Nara da Costa. Política nacional do idoso: retrospectiva histórica. Disponível em: <http://www.seer.ufrgs.br/RevEnvelhecer/article/ viewFile/4676/2593>. Acesso em: 25 out. 2015.

44 Art. 1ํ A política nacional do idoso tem por objetivo assegurar os direitos sociais do idoso, criando condições para promover sua autonomia, integração e participação efetiva na sociedade. BRASIL. Lei 8842 de 4 de janeiro de 1994. Disponível em: http: <//www.planalto.gov.br/ccivil_03/leis/L8842. htm>.Acesso em: 25 out. 2015.

45 RAMOS, Paulo Roberto Barbosa. Curso de direito do idoso. São Paulo: Saraiva, 2014, p.158. 
A referida lei traz o idoso como principal beneficiário de políticas sociais e transformações sociais, garantindo a efetivação das normas contidas na PNI.As diretrizes da Política foram contempladas no art. 4ํㅜㄹ tendo como referência a priorização do atendimento do idoso pela família em detrimento ao atendimento asilar, preferência de atendimento em órgãos públicos e privados, participação do idoso da implementação de políticas, programas, planos e projetos, viabilização da integração do idoso à sociedade ${ }^{46}$.

O Conselho Nacional do Idoso, que contempla um órgão com função de supervisionar, avaliar e acompanhar a efetivação na PNI, foi criado anos mais tarde, no ano de 2002, e atualmente, está inserido na Secretaria de Direitos Humanos da Presidência da República ${ }^{47}$.

O Estatuto do Idoso foi instituído, em 2003, para possibilitar

$\overline{46}$ Art. 4oㅡonstituem diretrizes da política nacional do idoso: I - viabilização de formas alternativas de participação, ocupação e convívio do idoso, que proporcionem sua integração às demais gerações; II - participação do idoso, através de suas organizações representativas, na formulação, implementação e avaliação das políticas, planos, programas e projetos a serem desenvolvidos; III - priorização do atendimento ao idoso através de suas próprias famílias, em detrimento do atendimento asilar, à exceção dos idosos que não possuam condições que garantam sua própria sobrevivência; IV - descentralização político-administrativa; V - capacitação e reciclagem dos recursos humanos nas áreas de geriatria e gerontologia e na prestação de serviços; VI - implementação de sistema de informações que permita a divulgação da política, dos serviços oferecidos, dos planos, programas e projetos em cada nível de governo; VII - estabelecimento de mecanismos que favoreçam a divulgação de informações de caráter educativo sobre os aspectos biopsicossociais do envelhecimento; VIII - priorização do atendimento ao idoso em órgãos públicos e privados prestadores de serviços, quando desabrigados e sem família; IX - apoio a estudos e pesquisas sobre as questões relativas ao envelhecimento. Parágrafo único. É vedada a permanência de portadores de doenças que necessitem de assistência médica ou de enfermagem permanente em instituições asilares de caráter social. BRASIL. Lei no 8.842 de 4 d e janeiro de 1994. Política nacional do idoso. Disponível em: <http://www.planalto. gov.br/ccivil_03/leis/L8842.htm>. http://www.planalto.gov.br/ccivil_03/ leis/L8842.htm Acesso em: 25 out. 2015.

47 SECRETARIA DE DIREITOS HUMANOS DA PRESIDENCIA DA REPÚBLICA. Participação social. Conselho Nacional dos Direitos do Idoso (CNDI). Disponível em: <http://www.sdh.gov.br/sobre/participacao-social/conselhonacional-dos-direitos-do-Idoso-CNDI>. Acesso em: 29 out 2015. 
a conscientização da sociedade sobre o envelhecimento. Esta reflexão provinda do diploma social que configura o estatuto tem o objetivo de planejar o impacto no sistema econômico e social derivado deste processo biológico natural que configura a velhice ${ }^{48}$.

A inserção do Estatuto no ordenamento jurídico possibilitou compromissar o comportamento dos cidadãos, agentes públicos e agentes privados no respeito aos direitos assegurados ao idoso constitucionalmente, concretizando a norma do art. 230 da Constituição Federal ${ }^{49}$.

Devido à ampliação nos conhecimentos na área do envelhecimento e saúde da pessoa idosa, a Lei 10.741 de 2003, aliada a Política Nacional do Idoso, trouxe regramentos especiais para alicerçar ações no sentido de possibilitar uma melhor qualidade de vida no decorrer do envelhecimento através de práticas de prevenção, promoção e reabilitação da saúde, tornando viável a vida em família e em sociedade ${ }^{50}$.

O Estatuto do Idoso, promulgado em 2003, tem como fim garantir os direitos do idoso, apregoando proteção integral a esta faixa etária por meio de suas normas. 0 art. $2^{\circ}$ do Estatuto ${ }^{51}$ destinou ao idoso todos os direitos fundamentais inerentes

48 COSTA, Eliane Romeiro. 0 estatuto do idoso no sistema de proteção social. p.1. Disponível em:http://www.fema.com.br/ direito/debora/sociologia/ estatuto_idoso/estatuto_idoso_sistema_protecao_social.pdf<http://www. fema.com.br/ direito/debora/antigos/sociologia/idoso/estatutoidoso_eliane. pdf>. Acesso em: 18 out. 2015.

49 ANDRIGHI, Fátima Nancy. 0 acesso do idoso ao judiciário. p.1. Disponível em: <http://www.egov.ufsc.br/portal/sites/default/files/anexos/1535815359-1-PB.pdf>.http://www.egov.ufsc.br/portal/sites/default/files/anexos/15358-15359-1-PB.pdf Acesso em: 18 out. 2015.

50 FERNANDES, Maria Terezinha de Oliveira; SOARES, Sonia Maria. o desenvolvimento de políticas públicas de atenção ao idoso no Brasil. Disponível em: <http://www.revistas.usp.br/reeusp/article/view/52841/0>.http://www. revistas.usp.br/reeusp/article/view/52841/56734 Acesso em 18 out. 2015.

51 Art. $2^{\circ} \mathrm{O}$ idoso goza de todos os direitos fundamentais inerentes à pessoa humana, sem prejuízo da proteção integral de que trata esta Lei, assegurando-se-lhe, por lei ou por outros meios, todas as oportunidades e facilidades, para preservação de sua saúde física e mental e seu aperfeiçoamento moral, 
a pessoa humana, já previstos na Constituição, aplicando-os de forma específica ao idoso ${ }^{52}$.

Consagrando as conquistas mais significativas da Carta de 1988, a liberdade e a dignidade humana, o Estatuto destinou, além destas garantias fundamentais, proteção integral ao idoso, de forma própria e detalhada. 0 art. $3^{053}$ assegura a prioridade na efetivação do direito à vida, à saúde, à alimentação, à educação, à cultura, ao esporte, ao lazer, ao trabalho, à cidadania, à liberdade, à dignidade, ao respeito e à convivência familiar e comunitária. Desta forma, prioriza-se ao idoso o direito à velhice digna ${ }^{54}$.

0 Estatuto do Idoso traz em seu artigo $2^{2}$ a premissa de que o idoso é titular de todos os direitos fundamentais inerentes à pessoa humana, tendo proteção integral aos direitos assegurados nesta Lei, cobrindo todas as possibilidades para garantir sua saúde física e mental, aperfeiçoamento moral intelectual, espiritual e social ${ }^{55}$. Apresenta, igualmente, a obrigação conjunta da

intelectual, espiritual e social, em condições de liberdade e dignidade. BRASIL. Lei 10.741 de 1 de outubro de 2003. Estatuto do Idoso. Disponível em: <http://www.planalto.gov.br/ccivil_03/leis/2003/L10.741.htm>. http://www. planalto.gov.br/ccivil_03/leis/2003/L10.741.htmAcesso em 11 out. 2015.

52 VILAS BOAS, Marco Antônio. Estatuto do idoso comentado. 5. ed. Rio de Janeiro: Forense, 2015, p.5

53 Art. $3^{\circ}$ É obrigação da família, da comunidade, da sociedade e do Poder Público assegurar ao idoso, com absoluta prioridade, a efetivação do direito à vida, à saúde, à alimentação, à educação, à cultura, ao esporte, ao lazer, ao trabalho, à cidadania, à liberdade, à dignidade, ao respeito e à convivência familiar e comunitária. BRASIL. Lei 10.741 de 1o de outubro de 2003. Estatuto do idoso. Disponível em: <http://www.planalto.gov.br/ccivil_03/ leis/2003/L10.741.htm>. http://www.planalto.gov.br/ccivil_03/leis/2003/ L10.741.htmhttp://www.planalto.gov.br/ccivil_03/leis/2003/L10.741.htmAcesso em: 18 out. 2015.

54 VILAS BOAS, Marco Antônio. Estatuto do idoso comentado. 5. ed. Rio de Janeiro: Forense, 2015, p.6.

55 Art. $2^{\circ} \mathrm{O}$ idoso goza de todos os direitos fundamentais inerentes à pessoa humana, sem prejuízo da proteção integral de que trata esta Lei, assegurando-se-lhe, por lei ou por outros meios, todas as oportunidades e facilidades, para preservação de sua saúde física e mental e seu aperfeiçoamento moral, intelectual, espiritual e social, em condições de liberdade e dignidade. BRASIL. 
família, comunidade, sociedade e Poder Público de garantir que os direitos previstos ao idoso sejam efetivados, incluindo prioridade no direito à vida, à saúde, à alimentação, à educação, à cultura, ao esporte, ao lazer, ao trabalho, à cidadania, à liberdade, à dignidade, ao respeito e à convivência familiar e comunitária ${ }^{56}$.

A obrigação de concretizar a proteção integral ao idoso prevista no Estatuto recai à família, à comunidade, à sociedade e ao Poder Público, conjuntamente. A Constituição Federal, da mesma forma, traz em seu art. $230^{57}$ o dever da família, sociedade e Estado em amparar o idoso e garantir o direito à vida.

0 parágrafo único do art. $3^{\circ}$ do Estatuto ${ }^{58}$, no que tange a

Lei 10.741 de 1 de outubro de 2003. Estatuto do Idoso. Disponível em: <http://www.planalto.gov.br/ccivil_03/leis/2003/L10.741.htm>.http://www. planalto.gov.br/ccivil_03/leis/2003/L10.741.htmAcesso em: 11 out. 2015;

56 Art. $3^{\circ}$ É obrigação da família, da comunidade, da sociedade e do Poder Público assegurar ao idoso, com absoluta prioridade, a efetivação do direito à vida, à saúde, à alimentação, à educação, à cultura, ao esporte, ao lazer, ao trabalho, à cidadania, à liberdade, à dignidade, ao respeito e à convivência familiar e comunitária. BRASIL. Lei 10.741 de 1o de outubro de 2003. Estatuto do idoso. Disponível em: <http://www.planalto.gov.br/ccivil_03/ leis/2003/L10.741.htm>.http://www.planalto.gov.br/ccivil_03/leis/2003/ L10.741.htm Acesso em: 11 out. 2015.

57 Art. 230. A família, a sociedade e o Estado têm o dever de amparar as pessoas idosas, assegurando sua participação na comunidade, defendendo sua dignidade e bem-estar e garantindo-lhes o direito à vida. BRASIL. Constituição da República Federativa do Brasil de 1988. Disponível em: <http://www. planalto.gov.br/ccivil_03/constituicao/ConstituicaoCompilado.htmhttp:// www.planalto.gov.br/ccivil_03/constituicao/ConstituicaoCompilado.htm>. Acesso em: 18 out. 2015.

58 Art. $3^{\circ}$. Parágrafo único. A garantia de prioridade compreende: I atendimento preferencial imediato e individualizado junto aos órgãos públicos e privados prestadores de serviços à população; II - preferência na formulação e na execução de políticas sociais públicas específicas;III - destinação privilegiada de recursos públicos nas áreas relacionadas com a proteção ao idoso; IV - viabilização de formas alternativas de participação, ocupação e convívio do idoso com as demais gerações; V priorização do atendimento do idoso por sua própria família, em detrimento do atendimento asilar, exceto dos que não a possuam ou careçam de condições de manutenção da própria sobrevivência; VI - capacitação e reciclagem dos recursos humanos nas áreas de geriatria e gerontologia e 
obrigação familiar, em nada inovou, considerando que esta já estava prevista na Carta Magna. Além do amparo familiar, traz como prioridade o atendimento preferencial em relação a outras faixas etárias, preferência no destino orçamentário para políticas públicas e sua execução, priorização do atendimento no cerne da família em detrimento ao atendimento asilar, salvo aqueles que careçam de condições para manter a própria sobrevivência, acesso à rede de saúde e assistência social em âmbito local, dentre outros. Estas especificações foram construídas com base na Lei 8.842 de 1994, que instituiu a Política Nacional do Idoso ${ }^{59}$.

\subsection{O PRINCÍPIO DA AFETIVIDADE E O DIREITO DE CONVIVENNCIA FAMILIAR}

A estrutura familiar é alvo de mudanças expressáveis e inimagináveis através do tempo. A família matrimonializada perdeu espaço para as diversas modalidades familiares, compostas por membros de todas as idades, e não necessariamente presente o casamento. Por meio de tais mudanças no caráter familiar, a Constituição Federal ${ }^{60}$ inovou ao reconhecer a família como base da sociedade, contando com a proteção estatal. Como entidade familiar pode considerar-se aquele agrupamento de pessoas ba-

na prestação de serviços aos idosos; VII - estabelecimento de mecanismos que favoreçam a divulgação de informações de caráter educativo sobre os aspectos biopsicossociais de envelhecimento; VIII - garantia de acesso à rede de serviços de saúde e de assistência social locais. IX - prioridade no recebimento da restituição do Imposto de Renda.BRASIL. Lei 10.741 de1o de outubro de 2003. Estatuto do idoso. Disponível em: <http://www.planalto.gov.br/ccivil_03/leis/2003/L10.741.htm>.http://www.planalto.gov. br/ccivil_03/leis/2003/L10.741.htmhttp://www.planalto.gov.br/ccivil_03/ leis/2003/L10.741.htm Acesso em: 11 out. 2015;

59 VILAS BOAS, Marco Antônio. Estatuto do idoso comentado. 5. ed. Rio de Janeiro: Forense, 2015, p. 6/7.

60 Art. 226. A família, base da sociedade, tem especial proteção do Estado. BRASIL. Constituição da República Federativa do Brasil de 1988. Disponível em: <http://www.planalto.gov.br/ccivil_03/constituicao/ConstituicaoCompilado.htmhttp://www.planalto.gov.br/ccivil_03/constituicao/ ConstituicaoCompilado.htm>. Acesso em: 3 jun. 2016. 
seado em laços de afeto, respeito e solidariedade, que buscam seu fundamento no bem-estar, na dignidade da pessoa humana, na igualdade, bem como na liberdade. ${ }^{61}$

A família prevista na Constituição atual foi fruto da evolução das entidades familiares, em quelentamente foi se perdendo a ideia patriarcal e de caráter imutável e indissolúvel da família e inserindo-se o sentimento de afetividade como pilar familiar. A nova família constitui seu fundamento no sentimento de afeto recíproco. ${ }^{62} \mathrm{~A}$ entidade de produção e o casamento como obrigação deram lugar a uma família de natureza socioafetiva, onde busca-se a felicidade ${ }^{63}$.

No compasso das famílias contemporâneas, estas se tornaram organizações indispensáveis à construção da identidade do indivíduo, sendo responsáveis pela inserção cultural e a consciência do desenvolvimento digno da pessoa humana. Dessa forma, além da família tradicionalmente matrimonializada, outras formas familiares mostraram-se cumpridoras destas funções ${ }^{64}$.

Regendo o direito de família, o princípio da afetividade separa-sedo sentimento de afeto, pois este não necessariamente é presente nas relações familiares ${ }^{65}$. A afetividade é dever jurídico

61 PADILHA, Elisangela. A constitucionalização do direito privado e a proteção dos direitos fundamentais nos novos arranjos familiares. Direitos Fundamentais \& Justiça. Pontifica Universidade Católica do Rio Grande do Sul. N. 33(out/dez 2015) Porto Alegre: HS Editora, 2015, p.168.

62 LOBO, Paulo. Direito civil: famílias. 3. ed. São Paulo: Saraiva, 2010. p. 65

63 FARIAS, Cristiano Chaves de; ROSENVALD, Nelson. Direito das famílias. 3. ed. Rio de Janeiro: Lumen Juis, 2011. p. 13

64 FARIAS, Cristiano Chaves de; ROSENVALD, Nelson. Direito das famílias. 3. ed. Rio de Janeiro: Lumen Juis, 2011. P. 13

65 Neste sentido: [..] A afetividade, como princípio jurídico, não se confunde com o afeto como fato psicológico ou anímico, porquanto pode ser presumida quando este faltar na realidade das relações; assim, a afetividade é dever imposto as pais em relação aos filhos e destes em relação àqueles, ainda que haja desamor ou desafeição entre eles. 0 princípio jurídico da afetividade entre pais e filhos apenas deixa de incidir com o falecimento de um dos sujeitos ou se houver perda do poder familiar. Na reação entre cônjuges e companheiros o princípio da afetividade incide enquanto houver afetividade real, pois esta 
que se impõe a pais, filhos e parentes, não sendo considerada a emoção que sustentam entre si. Este princípioencontra-se com o direito à convivência familiar e o princípio da igualdade, demonstrando que a família não decorre somente dos laços biológicos, mas também de ligações afetivas ${ }^{66}$.

O princípio da afetividade traz consigo a igualdade jurídica entre filhos biológicos e adotivos, no qual há o interesse em tutelar os direitos fundamentais de todos, através da consideração dos laços afetivos. Os interesses de ordem patrimonial não podem prevalecer em relação aos deveres recíprocos transcritos no princípio da afetividade.Desta forma, as melhores decisões acerca dos problemas em família decorrem da observância do princípio da afetividade ${ }^{67}$.

Da afetividade existente no cerne da família, surge a convivência familiar, que pode ser entendida como uma relação afetiva, presentes os requisitos de acontecer de forma diuturna e duradoura entre os que compõem o grupo familiar. Considerase comoo local onde as pessoas consideram-se reciprocamente protegidas, sendo um ninho regido pela solidariedade ${ }^{68}$.

O espaço de convivência familiar pressupõe uma identidade própria da família e construída de forma estável, não podendo ser aberta ao público. 0 espaço físico não essencialmentedeve se dar em casa, visto as atuais condições da sociedade, principalmente

é pressuposto da convivência. Até mesmo a afetividade real, sob o ponto de vista d direito, tem conteúdo conceptual mais estrito(o que une as pessoas com o objetivo de constituição de família) do que o empregado nas ciências da psique, na filosofia, nas ciências sociais, que abrange tanto o que une quanto o que desune(amor e ódio, afeição e desafeição, sentimento de aproximação e rejeição). [...]. Por isso, sem qualquer contradição, podemos referir a dever jurídico da afetividade oponível a pais e filhos e aos parentes entre si, em caráter permanente, independentemente dos sentimentos que nutram entre si, e aos cônjuges e companheiros enquanto durar a convivência [...]. LOBO, Paulo. Direito Civil: Famílias. 3. ed. São Paulo: Saraiva, 2010, p. 64/65.

66 LOBO, Paulo. Direito civil: famílias. 3. ed. São Paulo: Saraiva, 2010. p. 65.

67 LOBO, Paulo. Direito civil: famílias. 3. ed. São Paulo: Saraiva, 2010. p. 64-67.

68 LOBO, Paulo. Direito civil: famílias. 3. ed. São Paulo: Saraiva, 2010, p. 68. 
no que tange ao labor, contudo, deve-se estar presente a sensação de ambiente comum ${ }^{69}$.

Como bem fundada decisão em agravo de instrumento, a Oitava Câmara Cível do Tribunal de Justiça do Rio Grande do Sul ${ }^{70}$, definiu que é dever do Estado assegurar o direito de convivência familiar do idoso, previsto no Estatuto próprio. Dessa forma, a decisão foi proferida em medida protetiva ajuizada pelos filhos impedidos de visitar a mãe idosa que mora com uma das filhas e o genro, que não permitiam a visita da família, inclusive sendo agressivos com os mesmos.Determinaram os julgadores que a visitação deveria ocorrer com acompanhamento de policial e do oficial de justiça, visto que, na primeira visita deferida pelo juízo de origem, observou-se que a idosa teve muita alegria em receber a visita de seus filhos. Verifica-se com o relato deste caso, que a convivência familiar é benéfica ao idoso, mesmo que o Estado tenha que se fazer presente na ocasião da visita.

A família é indispensável ao bem-estar e cuidado de seus membros, porquanto é nela que são nutridos os sentimentos de proteção e segurança. Os grupos vulneráveis, como as crianças, adolescentes e idosos tem especial significado no antro da família, visto que necessitam de maior contribuição afetiva, o que reflete em seu desenvolvimento e saúde mental ${ }^{71}$.

69 LOBO, Paulo. Direito civil: famílias. 3. ed. São Paulo: Saraiva, 2010, p. 68.

70 ESTADO DO RIO GRANDE DO SUL. Tribunal de Justiça.Agravo de instrumento no 70046956207, Oitava Câmara Cível. Relator: Rui Portanova. Julgado em 4 de janeiro de 2012. Disponível em: <http://www.tjrs.jus.br/busca/ search?q=cache:www1.tjrs.jus.br/site_php/consulta/consulta_processo. php\%3Fnome_comarca\%3DTribunal\%2Bde\%2BJusti\%25E7a\%26versao\%3D\%26versao_fonetica\%3D1\%26tipo\%3D1\%26id_comarca\%3D700\%26num_ processo_mask\%3D70046956207\%26num_processo\%3D70046956207\%26 codEmenta\%3D4530652+++++\&proxystylesheet=tjrs_index\&clien-

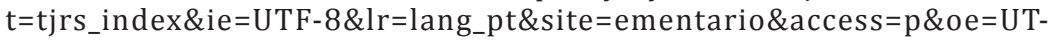
F-8\&numProcesso=70046956207\&comarca $=$ Comarca $\% 20$ de $\% 20$ Arroio $\% 20$ do\%20Tigre\&dtJulg=04/01/2012\&relator $=$ Rui $\% 20$ Portanova \&aba=juris $>$. Acesso em: 23 mai. 2016.

71 AQUINO, Luseni Maria Cordeiro; MELLO, Simone Gueresi; SILVA, Enid Rocha Andrade. Os abrigos para crianças e adolescentes e a promoção do direito à convivência familiar. Disponível em: <http://repositorio.ipea.gov. br/bitstream/11058/3050/10/Livro_cap.\%208>. Acesso em: 9 mai. 2016. 


\section{O IDOSO COMO VÍTIMA DE ALIENAÇÃO PARENTAL}

Para a discussão da possibilidade de aplicação análoga da Lei de Alienação Parental do idoso, importa definir em que consiste este fenômeno, e da mesma forma, estudar a legislação referente ao tema.

\subsection{ALIENAÇÃO PARENTAL: CONCEITO E IMPLICAÇÕES}

Os estudos acerca da Alienação Parental são incessantes, tendo a psicologia, a medicina e o direito unido esforços para o enfrentamento do tema.

A alienação parental, para Richard Gardner é um gênero onde insere-se seu cerne de estudos: a Síndrome de Alienação Parental, definida como:

A Síndrome de Alienação Parental (SAP) é um distúrbio da infância que aparece quase exclusivamente no contexto de disputas de custódia de crianças. Sua manifestação preliminar é a campanha denegritória contra um dos genitores, uma campanha feita pela própria criança e que não tenha nenhuma justificação. Resulta da combinação das instruções de um genitor (o que faz a "lavagem cerebral, programação, doutrinação") e contribuições da própria criança para caluniar o genitor-alvo. Quando o abuso e/ou a negligência parentais verdadeiros estão presentes, a animosidade da criança pode ser justificada, e assim a explicação de Síndrome de Alienação Parental para a hostilidade da criança não é aplicável ${ }^{72}$.

Defende o autor que existem diversas formas da criança alienar-se do genitor, como a negligência e o abuso parental, nem sempre configurando os sintomas que caracterizam a síndrome.

72 GARDNER, Richard. O DSM-IV tem equivalente para o diagnóstico da síndrome da alienação parental (SAP)? Disponível em: <http://www. alienacaoparental.com.br/textos-sobre-sap-1/o-dsm-iv-tem-equivalente>. Acesso em: 29 out. 2015. 
Constatada através de uma série de sintomas, a síndrome, em geral, individualiza-se pela presença, mesmo que sem ligação entre si, de sintomas que surgem em conjunto, tendo uma causa em comum.

A Síndrome de Alienação Parental, por sua vez, é mais específica que a alienação parental, pois tem a presença de uma série de sintomas psíquicos que culminam na programação para o ódio por um dos genitores, na tentativa de enfraquecer os vínculos psicológicos entre a criança e o genitor alienado. ${ }^{73}$

Jorge Trindade, através de estudos baseados nas obras de Gardner e Podevyn, conceitua alienação parental como uma forma de "programar uma criança para que odeie, sem justificativa, um de seus genitores, decorrendo daí que a própria criança contribui na trajetória de campanha de desmoralização"74.

Nesse contexto, a vítima de alienação parental é levada a crer que determinadas situações falsamente imputadas ao alienado são reais, sendo que acredita ter realmente acontecido, posto a forma insistente e recorrente que lhe são plantados os fatos. Dessa maneira, as falsas memórias inseridas passam a se tornar reais, não havendo distinção entre a verdade e a falsa existência dos fatos ${ }^{75}$.

A disputa pela guarda dos filhos é conflito real nos primeiros momentos após a separação do casal. Fantasias, medos e angústias tomam o imaginário dos pais, ainda não acostumados com a nova organização familiar. Dessa forma, caso o genitor seja psicologicamente debilitado, é comum instaurar-se uma crise, fruto

73 GARDNER, Richard. O DSM-IV tem equivalente para o diagnóstico da síndrome da alienação parental(SAP)? Disponível em: <http://www. alienacaoparental.com.br/textos-sobre-sap-1/o-dsm-iv-tem-equivalente>. Acesso em: 29 out. 2015.

74 TRINDADE, Jorge. Manual de psicologia jurídica par operadores do direito. 4. ed. Porto Alegre: Livraria do Advogado, 2010, p.177.

75 DIAS, Maria Berenice. Manual de direito das famílias. 7. ed. São Paulo: Editora Revista dos Tribunais, 2010, p.452. 
da instabilidade emocional, capaz de desencadear o processo de alienação parental ${ }^{76}$.

Essa crise permite a realização de vingança indireta, fruto da não aceitação do fim do relacionamento. Destarte, a criança é induzida a odiar o outro genitor, de forma programada pelo alienante, provocando uma contradição de sentimentos e a quebra de vínculos entre o filho e o genitor ${ }^{77}$.

Diante desta vingança interna, oriunda da confusão entre o fim da conjugalidade e da parentalidade, o genitor alienante transmite a ideia de que ambos foram abandonados pelo outro genitor, realizando uma lavagem cerebral na criança, numa campanha de afastamento do filho em relação ao pai ou mãe alienado ${ }^{78}$.

$\mathrm{Na}$ presença desta prática, as consequências para a criança vítima de alienação parental são inúmeras, como a depressão, dificuldades e isolamento social, transtornos de imagem e identidade, hostilidade, desorganização, e em alguns casos tendência ao uso de drogas, álcool e até ao suicídio. Na vida adulta, a pessoa pode apresentar sentimento de culpa pela injustiça feita em detrimento ao alienado ${ }^{79}$.

Ante a presença desta realidade fática, o ordenamento jurídico detectou a necessidade de criar dispositivos de lei para reconhecer e inibir essa modalidade de abuso. A psicologia teve grande participação na inspiração acerca da lei, contudo, seu texto disciplina de forma própria a atuação do Estado perante a alienação parental ${ }^{80}$.

76 TRINDADE, Jorge. Manual de psicologia jurídica par operadores do direito. 4. ed. Porto Alegre: Livraria do Advogado, 2010, p.178.

77 TRINDADE, Jorge. Manual de psicologia jurídica par operadores do direito. 4. ed. Porto Alegre: Livraria do Advogado, 2010, p.179.

78 DIAS, Maria Berenice (Coord.). Incesto e alienação parental. 3. ed. São Paulo: Revista dos Tribunais, 2013, p.104.

79FIORELLI, José Osmir; MANGINI, Rosana Cathya Ragazzoni. Psicologia jurídica. 2. ed. São Paulo: Atlas, 2010, p.308.

80 DIAS, Maria Berenice (Coord.). Incesto e alienação parental. 3. ed. São Paulo: Revista dos Tribunais, 2013, p.44. 
0 art. $2^{\circ}$ da Lei 12.318 de $2010^{81}$ traz o conceito jurídico de alienação parental, definido como a interferência na formação psicológica da criança ou adolescente, programando-a para repudiar o genitor de forma a dificultar os vínculos com este, promovida pelos genitores, avós ou qualquer outra pessoa que detenha autoridade, guarda ou vigilância ${ }^{82}$.

Infere-se deste artigo a preocupação em ampliar às demais pessoas inseridas no vínculo afetivo com a criança a possibilidade de alienação, tendo em vista evitar qualquer forma de disfarçar a prática deste abuso ${ }^{83}$.

Para a constatação da alienação parental, alguns erros precisam ser afastados, como a consideração apenas do depoimento da vítima, visto que este pode ser influenciado pelo alienador, permitir que apenas um dos genitores decida sobre a vida da criança, evitar terapia tradicional ao alienador, posto que necessita de tratamento especializado para a síndrome. Prática comum neste cenário tornase a dificuldade provocada pelo alienador de exercer o direito de visitas, evitando qualquer contato da vítima e alienado ${ }^{84}$.

0 parágrafo único do art. $2^{\circ}$ da Lei 12318 de $2010^{85}$ traz um rol exemplificativo das formas que a alienação parental pode ocorrer. Esse arrolamento auxilia o julgador para detectar com

81 Art. $2^{\circ}$ Considera-se ato de alienação parental a interferência na formação psicológica da criança ou do adolescente promovida ou induzida por um dos genitores, pelos avós ou pelos que tenham a criança ou adolescente sob a sua autoridade, guarda ou vigilância para que repudie genitor ou que cause prejuízo ao estabelecimento ou à manutenção de vínculos com este. BRASIL. Lei no 12.318 de 2010. Disponível em: <http://www.planalto.gov.br/ ccivil_03/_ato2007-2010/2010/lei/l12318.htm>. Acesso em: 30 out. 2015.

82 DIAS, Maria Berenice (Coord.). Incesto e alienação parental. 3. ed. São Paulo: Revista dos Tribunais, 2013, p. 48.

83 DIAS, Maria Berenice (Coord.). Incesto e alienação parental. 3. ed. São Paulo: Revista dos Tribunais, 2013, p. 46.

84 TRINDADE, Jorge. Manual de psicologia jurídica para operadores do direito. 4. ed. Porto Alegre: Livraria do Advogado, 2010, p.183/186.

85 BRASIL. Lei no 12.318 de 2010. Disponível em: <http://www.planalto.gov. br/ccivil_03/_ato2007-2010/2010/lei/l12318.htm>. Acesso em: 30 out. 2015. 
maior clareza a prática de alienação parental através de modelos costumeiros de comportamento, propiciando agilidade à adoção de medidas em fatos urgentes ${ }^{86}$.

Como formas exemplificativos de alienação parental contidas no parágrafo único do art. $2^{0}$ da Lei de Alienação Parental ${ }^{87}$, pode-se citar a campanha de desqualificação da conduta do genitor no exercício da paternidade ou maternidade;dificultar o exercício da autoridade parental; dificultar contato de criança ou adolescente com genitor; dificultar o exercício do direito regulamentado de convivência familiar; omitir deliberadamente a genitor informações pessoais relevantes sobre a criança ou adolescente, inclusive escolares, médicas e alterações de endereço; apresentar falsa denúncia contra genitor, contra familiares deste ou contra avós, para obstar ou dificultar a convivência deles com a criança ou adolescente; mudar o domicílio para local distante, sem justificativa, visando a dificultar a convivência da criança ou adolescente com o outro genitor, com familiares deste ou com avós.

Em ocasião de perícia, outras formas de conduta poderão ser apuradas pelo expert, além das já elencadas no referido artigo de lei, tendo o histórico familiar e o contexto em que praticados os atos suspeitos importante significado para a constatação da alienação parental. 0 perito designado para realizar o laudo acerca da existência ou não de alienação parental carece de conhecimento amplo no assunto, assim como a técnica necessária para compreender a interferência das emoções nas declarações. A perícia deve conter uma entrevista com os envolvidos, análise dos autos, histórico do relacionamento, avaliação de personalidade e da forma com que a criança se manifesta sobre acusação ao genitor ${ }^{88}$.

${ }^{86}$ DIAS, Maria Berenice (Coord.). Incesto e alienação parental. 3. ed. São Paulo: Revista dos Tribunais, 2013, p.48.

87 BRASIL. Lei no 12.318 de 2010. Disponível em: <http://www.planalto.gov. br/ccivil_03/_ato2007-2010/2010/lei/l12318.htm>. Acesso em: 30 out. 2015. 88 DIAS, Maria Berenice (Coord.). Incesto e alienação parental. 3. ed. São Paulo: Revista dos Tribunais, 2013. p. 50. 
Contudo, a perícia não é regra absoluta, porquanto, em casos onde o ato abusivo é evidente a intervenção judicial é devida. Em casos de pouca complexidade, o juiz poderá identificar com certa segurança a existência da alienação parental, adotando as medidas judiciais adequadas ao caso ${ }^{89}$.

\subsection{A VULNERABILIDADE DO IDOSO E SUA EQUIPARAÇÃO À CRIANÇA}

A previsão de vulnerabilidade da pessoa idosa encontra amparo na Constituição Federal, que abriga proteção específica à criança, ao adolesceste, ao jovem e ao idoso em seu capítulo VII, demonstrando o interesse do constituinte em resguardar especialmente os direitos previstos a estas figuras. Além disso, a Lei $8.069 / 90^{90}$ e a Lei $10.741 / 03^{91}$ preveem proteção integral às respectivas faixas etárias resguardadas.

Dessa forma, devido à vulnerabilidade do idoso estampada na Constituição Federal de 1988, é imprescindível a guarda legal aos direitos do idoso e, na falta de dispositivo específico, nada mais esperado que a aplicação análoga da lei 12.318 de 2010, conforme ordena a Lei Introdução as Normas do Direito Brasileiro ${ }^{92}$.

${ }^{89}$ DIAS, Maria Berenice (Coord.). Incesto e alienação parental. 3. ed. São Paulo: Revista dos Tribunais, 2013. p. 48.

90 Art. $1^{\circ}$. Esta Lei dispõe sobre a proteção integral à criança e ao adolescente. BRASIL. Lei 8.069 de 13 de julho de 1990. Disponível em: <http://www. planalto.gov.br/ccivil_03/leis/L8069Compilado.htm>. Acesso em: 22 abr. 2016.

91 Art. $2^{\circ} \mathrm{O}$ idoso goza de todos os direitos fundamentais inerentes à pessoa humana, sem prejuízo da proteção integral de que trata esta Lei, assegurando-se-lhe, por lei ou por outros meios, todas as oportunidades e facilidades, para preservação de sua saúde física e mental e seu aperfeiçoamento moral, intelectual, espiritual e social, em condições de liberdade e dignidade. BRASIL. Lei 10.741 de 1o de outubro de 2003. Disponível em:<http://www.planalto. gov.br/ccivil_03/leis/2003/L10.741.htm.>. Acesso em: 22 abr. de 2016.

92 Art. $4^{\circ}$ Quando a lei for omissa, o juiz decidirá o caso de acordo com a analogia, os costumes e os princípios gerais de direito. BRASIL. Decreto-Lei no 4657, de 4 de setembro de 1942. Lei de Introdução às normas do Direito Brasileiro. Disponível em: http://www.planalto.gov.br/ccivil_03/decreto-lei/ Del4657compilado.htm<http://www.planalto.gov.br/ccivil_03/decreto-lei/ Del4657.htm>. Acesso em: 11 out. 2015. 
A vulnerabilidade da pessoa idosa é identificável em nossa Carta Magna ${ }^{93}$. Preceitua o amparo ao idoso e à criança no mesmo capítulo constitucional, demarcando a fragilidade social que apresentam estas figuras. Logo, tanto a criança como o idoso necessitam de proteção integral aos seus direitos, afirmados pelo Estado.

No cenário moderno, as famílias são formadas por membros de diversas gerações, o que auxilia na ocorrência de conflitos. Tendo em vista as limitações naturais que o idoso percebe, há maior dificuldade de habitualidade com essa nova fase. Deste modo, alguns idosos necessitam de apoio para realizar as atividades cotidianas, sendo a família responsável por dar este suporte ao idoso, realçando e firmando os laços familiares ${ }^{94}$.

A proteção constitucional prevista ao idoso, à criança e ao adolescente sofre impulso dos princípios de solidariedade e proteção. Devido ao expressivo crescimento populacional desta faixa etária, tornou-se necessário a preocupação com a proteção do idoso. Todos os avanços tecnológicos e a melhoria na qualidade de vida da população contribuíram para que o ordenamento jurídico previsse maior proteção à pessoa de mais de 60 anos de idade ${ }^{95}$.

Como em países mais evoluídos, o Brasil, através da Constituição Federal de 1988, adotou maior cautela relacionada aos idosos, considerando esta uma questão social relevante, tendo em vista o aumento da expectativa de vida. Essa nova realidade

93 Capítulo VII Da Família, da Criança, do Adolescente, do Jovem e do Idoso. BRASIL. Constituição da República Federativa do Brasil de 1988. Disponível em: <http://www.planalto.gov.br/ccivil_03/constituicao/ConstituicaoCompilado.htm>.http://www.planalto.gov.br/ccivil_03/constituicao/ ConstituicaoCompilado.htm Acesso em: 11 out. 2015.

94 LEITE, Marinês Tambara. et al. Idosos residentes no meio urbano e sua rede de suporte familiar e social. Disponível em: <http://www.scielo.br/ scielo.php?script=sci_arttext\&pid=S0104-07072008000200005>. Acesso em: 11 mai. De 2016.

95 MARQUES, Claudia Lima; MIRAGEM, Bruno. O novo direito privado e a proteção dos vulneráveis. 2. ed. São Paulo: Revista dos Tribunais, 2014, p.146-147. 
populacional reflete na seguridade social, em que pese haver um número grande de aposentados e poucos contribuintes ${ }^{96}$.

Apesar de não estarem previstos expressamente no art. 6음 da Constituição Federal ${ }^{97}$, os direitos dos idosos têm a natureza de direitos sociais. Uma parte abrange a seguridade social, por meio da previdência social e o direitoà assistência social àquele que não puder prover sua própria subsistência. De outra banda, o art. 230 da Constituição prevê o dever de amparo as pessoas idosas, devendo a família, a sociedade e o Estado garantir sua inserção na comunidade, defender sua dignidade e bem-estar, bem como dar preferência convivência em seu lar ${ }^{98}$.

Por vezes, o idoso é o cerne da família, visto que necessita de certos cuidados, devido a sua fragilidade e dependência. A efetivação da legislação referente ao idoso tem o condão de insurgir o respeito ao idoso na sociedade, marchando assim para o reconhecimento do auxílio dos idosos na construção da nação, sendo sua inserção na sociedade, medida significativa para o aumento da própria autoestima ${ }^{99}$.

0 princípio da proteção integral é previsto ao idoso, à criança e ao adolescente, através do Estatuto do Idoso ${ }^{100}$ e do Estatuto da

96 MENDES, Gilmar Ferreira; COELHO, Inocêncio Mártires; BRANCO, Paulo Gustavo Gonet. Curso de direito constitucional. 5. ed. São Paulo: Saraiva, 2010, p.1556.

97 Art. 60 São direitos sociais a educação, a saúde, a alimentação, o trabalho, a moradia, o transporte, o lazer, a segurança, a previdência social, a proteção à maternidade e à infância, a assistência aos desamparados, na forma desta Constituição. BRASIL. Constituição da república federativa do brasil de 1988. Disponível em:<HTTP://WWW.PLANALTO.GOV.BR/CCIVIL_03/CONSTITUICAO/CONSTITUICAOCOMPILADO.HTM>.Acesso em: 11 mai. 2016.

98 MENDES, Gilmar Ferreira; COELHO, Inocêncio Mártires; BRANCO, Paulo Gustavo Gonet. Curso de direito constitucional. 5. ed. São Paulo: Saraiva, 2010, p. 317.

99 CAVALIERI FILHO, Sergio. Programa de sociologia jurídica. 12. ed. Rio de Janeiro: Forense, 2010, p. 153-154.

100 Art. $2^{0.0}$ idoso goza de todos os direitos fundamentais inerentes à pessoa humana, sem prejuízo da proteção integral de que trata esta lei, assegurando-se-lhe, por lei ou por outros meios, todas as oportunidades e facilidades, 
Criança e do Adolescente ${ }^{101}$, respectivamente. Dessa forma, deve o julgador estar atento a situações onde também o idoso esteja sendo influenciado por falsas ideias, transformando sentimentos e fatos diferentes da realidade, culminando no seu isolamento ${ }^{102}$.

Como forma comparativa da vulnerabilidade da criança e da pessoa idosa, confere-se que a proteção prevista no Código de Defesa do Consumidor, no que concerne a publicidade abusiva ${ }^{103}$, se amplia ao idoso, em casos em que as campanhas publicitarias prevalecem-se da restrição compreensiva do idoso ou de qualquer forma de aproveitamento da qualidade do idoso para imputar-lhe produtos ou serviços ${ }^{104}$.

A proteção dos vulneráveis abarca uma nova visão do direito, posto que os valores de tolerância e pluralismo de sujeitos devem ser observados. Para a solidificação das leis protetivas é precípua a atuação do judiciário para que o princípio da dignidade da pessoa humana seja efetivado ${ }^{105}$.

para preservação de sua saúde física e mental e seu aperfeiçoamento moral, intelectual, espiritual e social, em condições de liberdade e dignidade. BRASIL. Lei 10.741 de 1o de outubro de 2003. Estatuto do idoso. Disponível em: <http://www.planalto.gov.br/ccivil_03/leis/2003/l10.741.htm>. Acesso em: 12 mai. 2016.

${ }^{101}$ Art. 1ํㅡㄹ Esta Lei dispõe sobre a proteção integral à criança e ao adolescente. BRASIL. Lei 8.069 de 13 de julho de 1990. Estatuto da criança e do adolescente. Disponível em: <http://www.planalto.gov.br/ccivil_03/leis/L8069. htm>. Acesso em: 12 mai. 2016.

102 PODER JUDICIÁRIO DO ESTADO DO MATO GROSSO. Cartilha Alienação Parental. Disponível em: <http://www.tjmt.jus.br/intranet.arq/downloads/ Imprensa/NoticiaImprensa/file/2014/04\%20-\%20Abril/25\%20-\%20Cartilha\%20-\%20Aliena\%C3\%A7\%C3\%A3o.pdf>. Acesso em: 12 mai. 2016.

103 Art. 39. É vedado ao fornecedor de produtos ou serviços, dentre outras práticas abusivas:_IV - prevalecer-se da fraqueza ou ignorância do consumidor, tendo em vista sua idade, saúde, conhecimento ou condição social, para impingir-lhe seus produtos ou serviços; BRASIL. Lei 8.078 de 11 de setembro de 1990. Disponível em:<http://www.planalto.gov.br/ccivil_03/ leis/L8078.htm>. Acesso em: 17 mai. 2016.

104 MARQUES, Claudia Lima; MIRAGEM, Bruno. O novo direito privado e a proteção dos vulneráveis. 2. ed. São Paulo: Revista dos Tribunais, 2014, p.149.

105 MARQUES, Claudia Lima; MIRAGEM, Bruno. 0 novo direito privado e a proteção dos vulneráveis. 2. ed. São Paulo: Revista dos Tribunais, 2014, p. 109 


\subsection{A APLICAÇÃO ANÁLOGA E AS FORMAS INTERPRETATIVAS DA LEI}

Ante a possibilidade de resguardo ao direito de convivência familiar do idoso, infere verificar os métodos interpretativos compatíveis ao ordenamento jurídico brasileiro bem como a aplicação análoga da legislação.

A interpretação da lei é tarefa intricada, uma vez que diversos fatores influenciam para que a interpretação aconteçade forma coerente, levando em conta o contexto cultural e social, a metodologia e a posição do intérprete. Pode-se conceituar a interpretação normativa como um procedimento por meio do qual atribui-se sentido ao texto de lei, sendo que todo texto jurídico é passível de interpretação, seja a lei clara ou obscura. ${ }^{106}$ Desta forma, para uma justa interpretação legal, o intérprete deve se ater aos pressupostos contidos no texto da lei e no completo ordenamento jurídico.

A aplicação do direito pelo órgão judiciário é ato por meio do qual se constitui sentido às regras existentes, havendo, para tanto, uma interpretação. Versa-se um diálogo intelectual, em resposta a um questionamento; para interpretar qual conteúdo individual deve produzir à norma, aplicando ao caso concreto a previsão da lei.Utilizados todos os meios interpretativos, jamais será possível resultar em uma única interpretação certa, apenas em interpretações admissíveis ${ }^{107}$.

Como uma atividade puramente intelectual, a interpretação converte o direito positivado, que é uma norma abstrata e geral, em uma regra aplicável a casos reais, que tem natureza particular e concreta. Nesse seguimento, interpretar é um ato de dar sentido a generalidade da lei em face da situação fática, tendo em vista a

106 CARVALHO, Kildare Gonçalves. Direito constitucional. 17. ed. Belo Horizonte: Del Rey, 2011, p.294.

107 KELSEN, Hans. Teoria pura do direito. 8. ed. São Paulo: WMF Martins Fontes, 2009, p.387-392. 
distância que os separa. Dessa forma, a norma cumpre sua função de regular as circunstâncias concretas ${ }^{108}$.

Através do princípio da interpretação das leis em conformidade com a constituição, permite-se resultar uma interpretação conforme a constituição, perante casos de normas que apresentam uma abertura interpretativa. Nesse juízo, a melhor interpretação será aquela em que se pode haver uma hipótese de compreensão inequivocamente em conformidade com a constituição ${ }^{109}$.

Os meios de interpretação sobrevêm da interpretação gramatical da norma, da sistematicidade e da análise da sua finalidade. Estas formas interpretativas não podem ser consideradas de forma absoluta, devendo combinar-se para uma interpretação conjunta. Entretanto, apesar da unicidade da interpretação, pode o interprete atuar de forma subjetiva para aplicar as formas e realizar o julgamento, posto que não há hierarquia entre os meios interpretativos ${ }^{110}$.

A interpretação gramatical chama o intérprete a compreender o significado das palavras insculpidas no texto, sendo um interstício para a interpretação conforme a linguagem da lei. 0 limite para este tipo interpretativo é o próprio entendimento do sentido provável das palavras contidas no texto legal ${ }^{111}$. Essa técnica pressupões a procura do sentido literal da lei, devendo o intérprete estudar cada termo a fim de buscar sentido nos próprios vocábulos do texto ${ }^{112}$.

108 MENDES, Gilmar Ferreira; COELHO, Inocêncio Mártires; BRANCO, Paulo Gustavo Gonet. Curso de direito constitucional. 5. Ed. São Paulo: Saraiva, 2010. p. 108-/109

${ }^{109}$ CANOTILHO, José Joaquim Gomes. Direito constitucional e teoria da constituição. 7. ed. Coimbra: Almedina, 2003, p.1226-1227.

110 BARROSO, Luís Roberto. Interpretação e aplicação da constituição. 7. ed. São Paulo: Saraiva, 2009, p.129/130.

111 BARROSO, Luís Roberto. Interpretação e aplicação da constituição. 7. ed. São Paulo: Saraiva, 2009, p.131.

112 DINIZ, Maria Helena. Compêndio de introdução à ciência do direito. 17. ed. São Paulo: Saraiva, 2010, p.430-431. 
A sistematicidade interpretativa encontra respaldo na noção de ordem e integração do ordenamento jurídico. Desta forma, são estabelecidas conexões entre as normas jurídicas vigentes em todo o plano jurídico. Essa interpretação sistemática é um exame da estrutura das leis, uma perspectiva de todo o sistema legal, partindo-se, permanentemente, do entendimento de que a Constituição Federal é o pilar para qualquer interpretação da norma, devendo com ela ser conjugada ${ }^{113}$.

Atendendo à finalidade da lei, a interpretação teleológica busca investigar o sentido da norma, o bem jurídico tutelado pelo ordenamento por meio da lei. Todavia, a finalidade da lei não é imutável, visto que o fundamento racional da norma modifica-se, sem cessar a aplicação da norma. Portanto, a finalidade da lei evolui ao longo do tempo, sem, contudo, perder sua aplicabilidade, sendo que a interpretação, tanto das leis como da Constituição, deve ocorrer no sentido de melhor cumprir sua finalidade ${ }^{114}$.

À época da criação da lei, o legislador inclui suas intenções na norma, dessa forma, também constitui forma interpretativa a interpretação histórica, que busca sua tese nos precedentes legislativos, na ocasião de criação da lei e no sentido a ela atribuído no momento de sua concepção ${ }^{115}$. Desse modo, verifica-se os antecedentes da norma, desde sua iniciativa, analisando o contexto que lhe deu causa ${ }^{116}$.

Cabe ainda elucidar as formas interpretativas de acordo com a utilização dos métodos citados. A interpretação declarativa ocorre quando o elemento gramatical e o elemento lógico têm compatibilidade, isto é, seus sentidos são coincidentes. Havendo

113 BARROSO, Luís Roberto. Interpretação e aplicação da constituição. 7. ed. São Paulo: Saraiva, 2009, p.140.

114 BARROSO, Luís Roberto. Interpretação e aplicação da constituição. 7. ed. São Paulo: Saraiva, 2009, p.143/144

115 BARROSO, Luís Roberto. Interpretação e aplicação da constituição. 7. ed. São Paulo: Saraiva, 2009. p.136.

116 DINIZ, Maria Helena. Compêndio de introdução à ciência do direito. 17. ed. São Paulo: Saraiva, 2010, p.433. 
discrepância entre essas interpretações, observar-se-á duas formas interpretativas: a restritiva e a extensiva ${ }^{117}$.

As interpretações declarativa, restritiva e extensiva referem-se ao efeito obtido pelo aplicador ao interpretar a norma. A interpretação extensiva consiste em "pôr em realce regras e princípios não expressos, porém contidos implicitamente nas palavras do Código"118, ou melhor, o sentido dos termos é ampliado pois o legislador apenas previu uma ideia principal. Por meio restritivo de interpretação, a abrangência é exata, dessa forma, não se reduz o campo da norma, posto que delimita-se a fronteira precisa ${ }^{119}$.

Explicados os métodos clássicos de interpretação, cumpre ressaltar que o ordenamento jurídico é uno, perfazendo um sistema normativo que encontra solução dentro dele mesmo. Não obstante, a lei pode carecer de norma jurídica para regulamentação de determinados casos, apresentando omissão, lacuna ou silêncio. Para a resolução de eventuais faltas normativas, utiliza-se o processo de integração, onde cuida-se de utilizar uma norma pré-existente, mostrando seu sentido interpretativo no escopo de regular uma circunstância não conjecturada pelo legislador ${ }^{120}$.

0 direito é ciência dinâmica, que está infinitamente em movimentação para compreender e regular as novas tendências e necessidades da sociedade. Essedesenvolvimento social origina conflitos e fatos hodiernos, que são um desafio constante para os legisladores e aplicadores do direito, que por sua vez estabelecem precedentes e repensam valores para se adaptar ao dinamismo social ${ }^{121}$.

117 BARROSO, Luís Roberto. Interpretação e aplicação da constituição. 7. ed. São Paulo: Saraiva, 2009, p.125.

118 MAXIMILIANO, Carlos. Hermenêutica e aplicação do direito. 19. ed. Rio de Janeiro: Forense, 2010, p.162.

119 MAXIMILIANO, Carlos. Hermenêutica e aplicação do direito. 19. ed. Rio de Janeiro: Forense, 2010, p.164.

120 BARROSO, Luís Roberto. Interpretação e aplicação da constituição. 7. ed. São Paulo: Saraiva, 2009, p.146.

121 DINIZ, Maria Helena. Compêndio de introdução à ciência do direito. 17. ed. São Paulo: Saraiva, 2010, p.442. 
Embora o legislador procure minuciar a criação do texto legal, a lacuna eventualmente se fará presente, tendo em vista que este não poderá prever futuros casos, nem fatos que sobrevirão. Dessa forma, a lei figura como reguladora das relações atuais, bem como das futuras, sequer imaginadas pelo legislador. Para assegurar a justiça, pode-se estender um princípio abrangido em uma norma para tratar de um evento semelhante em seucerne, aplicando as disposições de forma análoga ${ }^{122}$.

Para tratar destas faltas normativas, o sistema jurídico brasileiro utiliza-se da analogia, que é a "aplicação de uma norma jurídica concebida para uma dada situação de fato a uma outra situação semelhante, mas que não fora prevista pelo legislador". É, portanto, meio usado diante de lacuna legal, que pode ocorrer quando há uma regra especifica que pode incidir ao caso e quando não há regra diretamente relacionada ao caso, devendo ser procurada através de uma análise sistemática na legislação. ${ }^{123}$ Sendo assim, confere a transferência das regras a outros episódios semelhantes, que apresentem correspondência axiológica expressiva, oferecendo tratamento jurídico idêntico ${ }^{124}$.

A analogia incide quando se pode prever questões semelhantes entre duas coisas, sendo presente circunstância de caráter essencial, isto é, aquela de que derivamas demais consequências. Analisados e presentes os aspectos semelhantes, denotando-se uma consequência íntima entre seus pontos, deduz-se que, se uma preposição é verdadeira a outra deverá ser ${ }^{125}$.

122 MAXIMILIANO, Carlos. Hermenêutica e aplicação do direito. 19. ed. Rio de Janeiro: Forense, 2010, p.170.

123 BARROSO, Luís Roberto. Interpretação e aplicação da constituição. 7. ed. São Paulo: Saraiva, 2009, p.147.

124 CANOTILHO, José Joaquim Gomes. Direito constitucional e teoria da constituição. 7. ed. Coimbra: Almedina, 2003, p.1236.

${ }^{125}$ MAXIMILIANO, Carlos. Hermenêutica e aplicação do direito. 19. ed. Rio de Janeiro: Forense, 2010, p. 168-70. 
Estabelece-se o método analógico após descobertas as semelhanças fundamentais e os elementos idênticos, transferindo os efeitos às hipóteses não antevistas pelo legislador. Assim sendo, aplica-se o direito de modo a garantir a efetivação do princípio da igualdade jurídica ${ }^{126}$, tratando de forma igual as espécies semelhantes ${ }^{127}$.

Para que a utilização da analogia não conduza a erros por parte do aplicador, alguns fatores devem ser considerados. Desse modo, para a aplicação análoga da lei, esta pressupõe que seja uma hipótese não prevista, o elemento de identidade e a análise do fato jurídico que deu origem ao dispositivo. Para a configuração da analogia "não bastam afinidades aparentes, semelhança formal; exige-se a real, verdadeira igualdade sob um ou mais aspetos, consistente no fato de se encontrar, num e noutro caso, o mesmo princípio básico e de ser uma só a ideia geradora"128. Nesse prisma, a hipótese deve ser assemelhada à regra existente tanto na essência como nos resultados.

Além das precauções supra, à analogia também se ressalta que é impraticável ignorar a natureza da lei, necessitando ser observado o ramo do direito para qual a norma foi criada. Da mesma forma, só se aplica a analogia a respeito do direito comum, e não do direito penal ou excepcional, nem em preceitos de restrição à liberdade e à outros direitos. No mais, exige a analogia o discernimento, o rigor lógico e a inteligência de quem a aplica ${ }^{129}$.

${ }^{126}$ Art. 5o Todos são iguais perante a lei, sem distinção de qualquer natureza, garantindo-se aos brasileiros e aos estrangeiros residentes no país a inviolabilidade do direito à vida, à liberdade, à igualdade, à segurança e à propriedade, nos termos seguintes:BRASIL. Constituição da República Federativa do Brasil de 1988. Disponível em: <http://www.planalto.gov.br/ccivil_03/ constituicao/ConstituicaoCompilado.htm>. Acesso em: 11 mai. 2016.

127 MAXIMILIANO, Carlos. Hermenêutica e aplicação do direito. 19. ed. Rio de Janeiro: Forense, 2010, p.171.

128 MAXIMILIANO, Carlos. Hermenêutica e aplicação do direito. 19. ed. Rio de Janeiro: Forense, 2010, p.173.

129 MAXIMILIANO, Carlos. Hermenêutica e aplicação do direito. 19. ed. Rio de Janeiro: Forense, 2010, p.172-173. 
Em decorrência ao processo análogo, o direito não será criado, mas puramente revelado pelo aplicador. Em casos de texto onde existem casos em rol de caráter taxativo a analogia não é admissível. Já em enumerações exemplificativas a analogia é aplicável, visto que não há restrições na aplicação do direito ${ }^{130}$.

Do estudo da interpretação extensiva e da analogia, insta distinguir suas diferenças, porquanto podem se confundir. De acordo com Carlos Maximiliano ${ }^{131}$ :

A analogia ocupa-se com uma lacuna do Direito Positivo, com hipótese não prevista em dispositivo nenhum, e resolve esta por meio de soluções estabelecidas para casos afins; a interpretação extensiva completa a norma existente, trata de espécie já regulada pelo Código, enquadrada no sentido de um preceito explícito, embora não se compreenda na letra deste.

Em síntese, a analogia configura-se quando da falta de dispositivo explícito, entendendo-se o princípio da norma, examinando uma concepção não considerada no texto legal. Na interpretação extensiva, a própria regra é estendida, através do rol vasto de significados estabelecido em uma norma já existente. ${ }^{132}$

\subsection{APLICAÇÃO ANÁLOGA DA LEI 12.318 DE 2010 AO IDOSO}

Vencidas as explicações acerca da ocorrência da aplicação análoga da lei no ordenamento jurídico pátrio, mister verificar a possibilidade de aplicação análoga face a Lei 12.318 de 2010.

130 MAXIMILIANO, Carlos. Hermenêutica e aplicação do direito. 19. ed. Rio de Janeiro: Forense, 2010, p.174.

131 MAXIMILIANO, Carlos. Hermenêutica e aplicação do direito. 19. ed. Rio de Janeiro: Forense, 2010, p.175.

132 MAXIMILIANO, Carlos. Hermenêutica e aplicação do direito. 19. ed. Rio de Janeiro: Forense, 2010, p.175. 
Do estudo da referida lei, observa-se que seu intuito é garantir ao vulnerável seu direito de convivência familiar, ceifado por membro da família ou de suas relações afetivas através da influência psicológica para o repúdio ao alienado. Daí esclarecem-se os pontos de semelhança essenciais à aplicação análoga da legislação face ao idoso, posto que o bem tutelado trata-se do mesmo: a convivência familiar e a integridade psicológica da vítima.

Nesse contexto, importa discutir se o fenômeno é favorável à aplicação análoga ou a interpretação extensiva, devido suas confrontações. Para a tutela do idoso alienado, a aplicação análoga apresenta-se como a forma que melhor se adequa ao caso, posto que na interpretação extensiva há a intenção do legislador em regular a situação, estando esta inserida em uma gama de significados presentes na Lei. Dessa forma, é nítido o intuito da Lei 12.318 de $2010^{133}$ em proteger a criança e o adolescente, não se tratando de mera interpretação extensiva.

Para a analogia, necessário se faz a existência de uma falta normativa, mas que admita o mesmo fato jurídico como instauração. No caso em discussão, o fato institutivo é a campanha de desmoralização do alienado, que pode ocorrer de várias formas, previstas em lei ou verificadas em perícia. Como pontos de semelhança, cita-se a vulnerabilidade da vítima, o intuito de proteger a convivência familiar e a tutela da dignidade, bem-estar e desenvolvimento psíquico.

Consoante os estudos decorrentes da maneira em que a aplicação análoga ocorre, infere-se que esta somente poderá ser aplicada em casos em que a legislação traga um rol exemplifica-

${ }^{133}$ Art. $2^{\circ}$. Considera-se ato de alienação parental a interferência na formação psicológica da criança ou do adolescente promovida ou induzida por um dos genitores, pelos avós ou pelos que tenham a criança ou adolescente sob a sua autoridade, guarda ou vigilância para que repudie genitor ou que cause prejuízo ao estabelecimento ou à manutenção de vínculos com este. BRASIL. Lei no 12.318 de 2010. Disponível em: <http://www.planalto.gov.br/ ccivil_03/_ato2007-2010/2010/lei/l12318.htm>. Acesso em: 30 out. 2015. 
tivo de condutas incompatíveis à legislação. Os casos semelhantes, portanto, não podem partir de acontecimentos taxativos. $\mathrm{Na}$ análise em tela, tendo o parágrafo único do art. $2^{\circ}$ da Lei 12.318 de 2010 caráter exemplificativo, podendo haver outras formas alienação parental a serem descobertas em perícia, nada obsta que ocorra a aplicação análoga.

A sociedade contemporânea originou o pluralismo de sujeitos de direito, dessa forma, grupos até então desprotegidos tornaram-se juridicamente tutelados pelo direito positivo. Essa normatização das situações de fato, como o reconhecimento do afeto, das várias formas familiares, da proteção à criança e ao idoso, enseja a participação eficaz do intérprete para realizar a vinculação necessária entre a norma existente e a realidade fática, tendo em vista o propósito de proteção e efetivação dos direitos fundamentais ${ }^{134}$.

Como defesa da aplicação da Lei 12.318 de 2010 além da criança e do adolescente insta estudar o voto do Des. Rui Portanova, da Oitava Câmara Cível do Tribunal de Justiça do Rio Grande do Sul, apesar de vencido, no julgamento da Apelação Cível de no 70067792564 . Tal acórdão teve como discussão a extinção do feito que a mãe pleiteava guarda, visitação, bem como a possibilidade de alienação parental instigada pelo pai guardião, tendo em vista a maioridade dos adolescentes no decorrer do processo.

Em suas razões, o desembargador sustenta que a Lei 12.318 de 2010 deve ser analisada sob o prisma da Constituição Federal, na qual está previsto o direito à convivência familiar, inclusive por ter sido previsto na redação do art. 227 da Carta, o jovem, projetando sua proteção além da criança e do adolescente. De tal modo, explicita:

${ }^{134}$ MARQUES, Claudia Lima; MIRAGEM, Bruno. 0 novo direito privado e a proteção dos vulneráveis. 2. ed. São Paulo: Revista dos Tribunais, 2014, p.108. 
Nesse passo, por analogia com o que ocorre nas ações de alimentos em que o filho implementa a maioridade durante o curso da ação, também em casos como o presente, poder-se-ia pensar em seguir, dentro destes autos, com o processo. Regularizada, é claro, a citação dos jovens.

Vale a pena lembrar os processos em que o Poder Judiciário atua viabilizando visitações de filhos adultos em relação a pais idosos.

Como visto estou em que é induvidoso o interesse dos filhos, ainda mais maiores de idade, de acompanhamento das investigações de tamanha relevância para sua vida, saúde e formação.

Enfim, guardo alguma resistência em admitir que os filhos jovens não podem ser alcançados pelo Direito de Família, como um todo (na medida das possibilidades) e na investigação das possibilidades do exercício da visitação por mães e pais, mais especificamente.

Certo, tanto quanto acontece com crianças e adolescente, não se vá obriga forçadamente a uma visitação indesejada entre os pais e seus jovens filhos. 0 poder do Poder Judiciário tem seu limites na realidade. Mas o Estado-juiz não pode fugir da possibilidade de seu protagonismos nas conciliação dos $\operatorname{conflitos}^{135}$.

135 ESTADO DO RIO GRANDE DO SUL. Tribunal de Justiça.Apelação Cível de no 70067792564, Oitava Câmara Cível. Relator: Luiz Felipe Brasil Santos. Julgado em 3 de março de 2016. Disponível em: <http://www. tjrs.jus.br/busca/search?q=cache:www1.tjrs.jus.br/site_php/consulta/ consulta_processo.php\%3Fnome_comarca\%3DTribunal\%2Bde\%2BJusti\%25E7a\%26versao\%3D\%26versao_fonetica\%3D1\%26tipo\%3D1\%26id_comarca\%3D700\%26num_processo_mask\%3D70067792564\%26num_processo\%3D70067792564\%26codEmenta\%3D6739133+++++\&proxystylesheet=tjrs_index\&client=tjrs_index\&ie=UTF-8\&lr=lang_pt\&site=ementario\&access $=$ p \&oe $=U$ TF $-8 \&$ numProcesso $=70067792564 \&$ comarca $=$ Comarca $\% 20$ de $\% 20$ Porto $\% 20$ Alegre \&dtJulg=03/03/2016\&relator=Luiz $\% 20$ Felipe $\% 20$ Brasil\%20Santos\&aba=juris>. Acesso em: 23 mai. 2016. 
Pelas explanações do desembargador, observa-se a preocupação em esclarecer que a alienação parental deve ser discutida judicialmente,poispraticada em detrimento do vulnerável, sendo direito também do jovem de conhecer dessa situação, visto que pode sofrer influência em sua formação psicológica.

Como bem referido pelo Des. Rui Portanova, deve-se observar, a vontade das pessoas quando se trata da visitação de adultos, podendo citar-se, neste intermédio, o princípio da autonomia da vontade ${ }^{136}$.A convivência é direito de pais e filhos, contudo, não pode ser imposição absoluta do judiciário quando envolver adultos em plena capacidade, bem como idosos em condições manifestas de discernimento.

A partir de todas as garantias previstas ao idoso, com base no princípio maior da dignidade da pessoa humana, na vulnerabilidade do idoso, no seu direito de convivência familiar e na doutrina da proteção integral prevista pelo Estatuto do Idoso, a aplicação análoga da Lei 12.318 de 2010 é medida necessária para garantir a proteção ao idoso privado de sua convivência familiar, instigado ao ódio pela família provocado por seus filhos ou cuidadores ${ }^{137}$.

${ }^{136}$ Sobre: [...] Todas as vezes que as regras jurídicas aludem a suportesfáticos, emque a vontade seja um dos elementos, admitem elas que esses suportes fáticos se componham ou não componham. Dizem, também, até onde se pode querer. Portanto, supõe-se que alguém queira ou não queira. 0 auto-regramento, a chamada 'autonomia da vontade', não é mais do que isso. A vida social tece-se com interesses, em relações inter-humanas, que necessariamente ultrapassam e ficam aquém da esfera jurídica, isto é, da zona colorida em quea) os fatos se fazem jurídicos, b) relações nascidas independentemente do direito se tornam jurídicos, e c) relações jurídicas, nascidas, portanto, no direito, seestabelecem. [...] Ainda assim não a prendem de todo, e deixam campo de ação, em que a relevância jurídica não implique disciplinação rígida da vida em comum. Já aqui se pode caracterizar oque passa, em verdade, com os atos humanos interiores ao campo de atividade, a que se chama auto-regramento da vontade, 'autonomia privada', ou 'autonomia da vontade', é o espaço deixado às vontades, sem se repelirem do jurídico tais vontades.[...] MIRANDA, Pontes de. Tratado de Direito Privado. V. 3. Campinas: Bookseller, 2000.

137 BASTOS, Maria Ísis de Araujo; CAMPOS, Carolinne Pinheiro. 0 idoso como vítima de alienação parental: nova possibilidade interpretativa do art. $2^{\circ}$ o da Lei 12.318 de 2010. Disponível em: <http://www.publicadireito.com.br/ artigos/?cod=fa873e7f272a69e1>. Acesso em: 29 de mai. 2016. 
No mesmo sentido é o entendimento da Cartilha sobre Alienação Parental do Poder Judiciário do Mato Grosso ${ }^{138}$, na qual verifica que por vezes o idoso é impedido pelos filhos ou curadores de manter vínculos com os parentes e amigos. Nessa situação, analisado o caso concreto e as demais circunstâncias de fato, como o interregno entre o contato obrigatório e a liberdade das pessoas, defende os criadores da Cartilha, que a aplicação análoga da lei 12.318 de 2010 torna-se cabível, posto que tanto o idoso como a criança contam com proteção integral a seus direitos e não podem ser privados de conviverem com a família.

\subsection{POSSÍVEIS IMPLICAÇÕES JURÍDICAS DO RECONHECIMENTO DA APLICAÇÃO ANÁLOGA}

Debatida e analisada a possibilidade de aplicação análoga da Lei de alienação parental quando a prática é observada em relação ao idoso, impende examinar as possíveis decorrências jurídicas após a constatação do abuso em desfavor ao idoso, para resguardar seu direito de convivência familiar, cumulado ao direito à vida digna e bem-estar.

Ante indícios da prática de alienação parental, preceitua a Lei 12.318 de 2010 que deve o juiz a qualquer momento tomar as decisões cabíveis, analisadas as circunstancias fático-probatórias do processo, seja principal ou incidental, apreciado pelo Ministério Público, a fim de garantir a integridade psicológico da vítima, bem como resguardar a convivência familiar. In verbis:

Art. 4ํㅡㄹ Declarado indício de ato de alienação parental, a requerimento ou de ofício, em qualquer momento processual, em ação autônoma ou incidentalmente, o processo terá tramitação prioritá-

138 PODER JUDICIÁRIO DO ESTADO DO MATO GROSSO. Cartilha Alienação Parental. Disponível em: <http://www.tjmt.jus.br/intranet.arq/downloads/ Imprensa/Noticialmprensa/file/2014/04\%20-\%20Abril/25\%20-\%20Cartilha\% 20-\%20Aliena\%C3\%A7\%C3\%A3o.pdf > 
ria, e o juiz determinará, com urgência, ouvido o Ministério Público, as medidas provisórias necessárias para preservação da integridade psicológica da criança ou do adolescente, inclusive para assegurar sua convivência com genitor ou viabilizar a efetiva reaproximação entre ambos, se for o caso.

Parágrafo único. Assegurar-se-á à criança ou adolescente e ao genitor garantia mínima de visitação assistida, ressalvados os casos em que há iminente risco de prejuízo à integridade física ou psicológica da criança ou do adolescente, atestado por profissional eventualmente designado pelo juiz para acompanhamento das visitas.

Nesses termos, conforme observa-se no julgamento do Agravo de Instrumento de no 70067690586 da Sétima Câmara Cível do Tribunal de Justiça do Rio Grande do Sul ${ }^{139}$, a reversão da guarda pode ser feita em sede antecipatória, quando demonstrada a prática de alienação parental através de perícias sociais, psicológicas ou psiquiátricas, sendo que o bem-estar do vulnerável é de maior valor que qualquer outro interesse. Nesse sentido, não há o que se falar em guarda do idoso, porém, a tutela ou a curatela podem ser discutidas, se for o caso; no entanto, sempre no intuito de preservar os interesses do idoso, bem como os da criança.

139 ESTADO DO RIO GRANDE DO SUL. Tribunal de Justiça. Agravo de instrumento no 70067690586, Sétima Câmara Cível. Relator Des. ${ }^{a}$ Sandra Brisolara Medeiros. Julgado em 16 de março de 2016. Disponível em: <http://www.tjrs.jus.br/busca/search?q=cache:www1.tjrs.jus.br/ site_php/consulta/consulta_processo.php\%3Fnome_comarca\%3DTribunal\%2Bde\%2BJusti $\% 25 \mathrm{E} 7 \mathrm{a} \% 26$ versao\%3D\%26versao_fonetica\%3D1\%26tipo\%3D1\%26id_comarca\%3D700\%26num_processo_mask\%3D70067690586\%26num_processo\%3D $70067690586 \% 26$ codEmenta\%3D6692866+70067690586++++\&proxystylesheet=tjrs_index\&clien$\mathrm{t}=\mathrm{tjrs} \_i n d e x \& i e=U T F-8 \& l r=l a n g \_p t \& s i t e=$ ementario \&access $=$ p \&oe $=U-$ TF-8\&numProcess $0=70067690586 \&$ comarca $=$ Co $\operatorname{marca} \% 20 \mathrm{de} \% 20$ S\%C3\%A3 o\%20 Leopoldo\&dtJulg=16/03/2016\&relator $=$ Sandra \%20 Brisolara\%20Medeiros\&aba=juris>. Acesso em: 23 mai. 2016. 
Em outro julgado de no $70067827527^{140}$, da mesma Câmara Cível, o relator menciona que a ponderação dos interesses da criança abrange diversos aspectos, sendo que estes influenciam em fatores como o desenvolvimento físico mental, a qualidade dos relacionamentos afetivos, sintetizando em sua felicidade.

Em agravo de instrumento desprovido visando desconstituir a decisão interlocutória que deferiu a visitação da filha ao pai idoso, bem ilustrou o relator Jorge Luis Dall'Agnol, ao exaltar a visitação como direito não somente do pai e da mãe, como também do filho, dado que o direito de convivência deve ser assegurado mesmo que ambos não residam sob o mesmo teto. Dessa forma:

\begin{abstract}
Não se pode obstaculizar a convivência paterno filial, principalmente diante da ausência de prova de que as visitas da filha possam causa risco à integridade do genitor. Ao contrário, a visitação visa preservar a convivência familiar, objetivando a manutenção do vínculo afetivo existente, o que irá, inclusive, repercutir em favor do próprio agravante ${ }^{141}$.
\end{abstract}

140 ESTADO DO RIO GRANDE DOS SUL. Tribunal de Justiça. Agravo de Instrumento no 70067827527,Sétima Câmara Cível. Relator: Sergio Fernando Silva de Vasconcellos Chaves. Julgado em 16 de março de 2016. Disponível em: <http://www.tjrs.jus.br/busca/search?q=cache:www1.tjrs.jus.br/site_php/ consulta/consulta_processo.php\%3Fnome_comarca\%3DTribunal\%2Bde\%2BJusti\%25E7a\%26versao\%3D\%26versao_fonetica\%3D1\%26tipo\%3D1\%26id_ comarca\%3D700\%26num_processo_mask\%3D70067827527\%26num_processo\%3D70067827527\%26codEmenta\%3D6694659+++++\&proxystyleshee$\mathrm{t}=\mathrm{tjrs} \_$index\&client=tjrs_index\&ie $=U \mathrm{UTF}-8 \& \mathrm{lr}=$ lang_pt $\&$ site $=$ ementario\&ac cess $=$ p\&oe $=U T F-8 \&$ numProcesso $=70067827527 \&$ comarca $=$ Comarca $\% 20$ de\%20Porto \%20Alegre\&dtJulg=16/03/2016\&relator $=S \% C 3 \%$ A9rgio $\% 20$ Fernando\%20de\%20Vasconcellos\%20Chaves\&aba=juris?>. Acesso em: 23 mai. 2016.

141 ESTADO DO RIO GRANDE DO SUL. Tribunal de Justiça. Agravo de instrumento no 70065085839, Sétima Câmara Cível. Relator Des.Jorge Luis Dall'Agnol. Julgado em 26 de agosto de 2015. Disponível em: <http://www. tjrs.jus.br/busca/search?q=cache:www1.tjrs.jus.br/site_php/consulta/ consulta_processo.php\%3Fnome_comarca\%3DTribunal $\% 2$ Bde $\% 2$ BJusti\%25E7a\%26versao\%3D\%26versao_fonetica\%3D1\%26tipo\%3D1\%26id_comarca\%3D700\%26num_processo_mask\%3D70065085839\%26num_proces- 
Observa-se nessa circunstância, conforme acórdão proferido, que o idoso, além da idade avançada, encontrava-se acometido por problemas de saúde. De acordo com as provas carreadas aos autos, o relacionamento entre pai e filha sempre foi contínuo, demonstrando um enlace afetivo muito forte, mediante convivência benéfica, mesmo após o divórcio dos pais. Após esta separação, o idoso passou a morar com uma companheira, e a partir de então a filha teve dificuldades de visitação ao pai.Dessa forma, restou mantida a decisão antecipatória de $1^{\circ}$ grau que deferiu a visitação em sábados alternados das $10 \mathrm{~h}$ às $18 \mathrm{~h}$, aguardando a produção de mais provas, podendo a determinação ser revista a qualquer tempo.

Pode-se considerar, pela mera análise do acórdão supra referido, que há indícios de uma possível alienação parental face à situação fática observada. Considerando o bom relacionamento entre pai e filha, demonstrada a afetividade natural anterior à constituição de novo relacionamento amoroso, havendo, após, resistência do idoso em relação à visitação da filha. Por óbvio, a conduta alienante só poderia ser esclarecida através de instauração de incidente de alienação parental, havendo perícia psicológica, tendo como escopo os envolvidos: pai, filha e companheira do pai.

Nesse ensejo, constatada a prática de alienação parental, observadas as hipóteses do parágrafo único do art. $2^{\text {o }}$ da Lei 12.318 de 2010, ainda consideradas eventuais constatações em laudo pericial, a advertência da companheira do idoso acometido de doença se tornaria medida cabível para garantir sua dignidade e o direito de convivência familiar de pai e filha. Ressalte-se que a perícia é elemento indispensável para a constatação da alienação,

so\%3D70065085839\%26codEmenta\%3D6466066+++++\&proxystyleshee$\mathrm{t}=\mathrm{tjrs} \_$index\&client=tjrs_index\&ie=UTF-8\&lr=lang_pt $\&$ site $=$ ementario\&access $=$ p \&oe $=U T F-8 \&$ numProcesso $=70065085839 \&$ comarca $=$ Comarca $\% 20$ de $\% 20$ Lajeado\&dtJulg=26/08/2015\&relator=Jorge $\% 20 \mathrm{Lu} \%$ C3\%ADs $\% 20$ Dall\%27Agnol\&aba=juris?>. Acesso em: 23 mai. 2016. 
para que a decisão seja baseada no melhor interesse do idoso, tendo em vista, da mesma forma, sua capacidade civil, sempre no intuito de viabilizar a reconciliação familiar e garantir sua integridade psicológica, além de observar a vontade e o interesse do idoso dentre as circunstâncias.

Diante da constatação probatória da prática de alienação parental, o juiz deverá aplicar as sanções cabíveis, sem prejuízo da responsabilidade criminal e civil, consoante art. 6ํ da Lei de Alienação Parental ${ }^{142}$ :

Art. 6ํㅡㄹ Caracterizados atos típicos de alienação parental ou qualquer conduta que dificulte a convivência de criança ou adolescente com genitor, em ação autônoma ou incidental, o juiz poderá, cumulativamente ou não, sem prejuízo da decorrente responsabilidade civil ou criminal e da ampla utilização de instrumentos processuais aptos a inibir ou atenuar seus efeitos, segundo a gravidade do caso:

I - declarar a ocorrência de alienação parental e advertir o alienador;

II - ampliar o regime de convivência familiar em favor do genitor alienado;

III - estipular multa ao alienador;

IV - determinar acompanhamento psicológico e/ ou biopsicossocial;

V - determinar a alteração da guarda para guarda compartilhada ou sua inversão;

VI - determinar a fixação cautelar do domicílio da criança ou adolescente;

VII - declarar a suspensão da autoridade parental. Parágrafo único. Caracterizado mudança abusiva de endereço, inviabilização ou obstrução à convivência familiar, o juiz também poderá inverter a obrigação de levar para ou retirar a criança ou ado-

${ }^{142}$ BRASIL. Lei 12.318 de 26 de agosto de 2010. Disponível em: <http://www. planalto.gov.br/ccivil_03/_ato2007-2010/2010/lei/l12318.htm>. Acesso em: 23 mai. 2016. 
lescente da residência do genitor, por ocasião das alternâncias dos períodos de convivência familiar.

Desse artigo depreende-se que há ampla aplicabilidade em casos onde a vítima é pessoa idosa, tendo em conta que visa garantir a permanente convivência familiar com o alienado e a inibir a pratica de alienação parental através da advertência, multa, acompanhamento psicológico.

\section{CONSIDERAÇÕES FINAIS}

0 direto à vida é um direito fundamental, que, assim como os demais, decorre do princípio da dignidade da pessoa humana, que é um dos fundamentos da República. Deste modo, o direito a uma velhice digna é extensão do direito fundamental à vida, garantindo a plenitude da pessoa humana em todas as fases de seu desenvolvimento.

Os idosos experimentaram seus direitos positivados no ordenamento jurídico brasileiro através da Constituição Federal de 1988, que deu especial proteção a essas pessoas, juntamente com a família, a criança e o jovem, em capítulo específico. Ademais, a Política Nacional do Idoso e o Estatuto do Idoso tem a finalidade de definir a aplicação da proteção integral aos maiores de 60 anos.

Nesse diapasão, insurge a figura do idoso privado do seu direito de convivência familiar em decorrência da prática de alienação parental. Delimita a Lei 12.318 de 2010 que a vítima de alienação parental é a criança ou adolescente.A Lei de alienação parental, segundo verificado, intenta rechaçar qualquer posicionamento de modo a denegrir a imagem de membro familiar próximo ao vulnerável, tendo em vista proteger seu direito de convivência, garantindo seu desenvolvimento psicológico sadio.

Conforme demonstrado, o idoso automaticamente apresenta características de vulnerabilidade, independentemente de estar 
acometido de doenças mentais ou físicas, posto que nessas condições a vulnerabilidade acentua-se. A Constituição Federal de 1988 e a legislação infraconstitucional previram tutela especial às crianças, adolescentes e idosos, de modo a garantir a proteção integral de seus direitos, inclusive através de Estatuto próprio.

Assim, constata-se que a aplicação análoga lei de alienação parental é possível tendo em vista que a analogia é instituto utilizado para normatizar acontecimento de fato que não foi previsto pelo legislador, contudo, que contenha semelhança e pontos essenciais de igualdade com norma pré-existente. Ainda neste contexto, as formas interpretativas abrem ensejo de compreender o idoso como vítima de alienação parental, frente sua condição de vulnerável, bem como a criança e o adolescente.

Nota-se pela análise superficial da jurisprudência que o poder judiciário não tem se preocupado em discutir a possibilidade de alienação parental em detrimento ao idoso, apesar do posicionamento do Tribunal de Justiça do Mato Grosso a favor da utilização análoga. A alienação parental, apesar de abuso estudado há décadas pela psicologia, é fenômeno de legislação recente. Sendo assim, sua aplicação é realizada de forma cautelosa, tendo em vista o melhor interesse da criança e do adolescente.

Como resolução prática e célere para coibir a prática de alienação em detrimento ao idoso, se faz necessário a aplicação análoga da lei 12.318 de 2010, levando-se em consideração o seu intuito em proteger o direito de convivência familiar do vulnerável, bem como garantir seu saudável desenvolvimento psicológico.

Para a regularização e até mesmo a prevenção de um abuso psicológico contra o idoso, seria imprescindível a criação de dispositivo de lei específico para a alienação parental do idoso. Nesta senda, a apuração da existência de alienação parental se daria nos moldes da ação de alienação parental em relação à criança e ao adolescente, posto sua equiparação em vulnerabilidade, sendo analisado o melhor interesse da vítima em qualquer 
decisão, podendo ser verificada em ação autônoma ou incidental, utilizada a perícia psicológica para sua constatação.

A ordem jurídica não pode prever todos os conflitos existentes na sociedade, uma vez que o processo legislativo ocorre em diferentes épocas e os costumes sociais estão em constante transição. A interpretação análoga é um dos meios previstos para sanar estas falhas normativas que porventura venham a ser encontradas pelo Poder Judiciário no exercício jurisdicional do Estado, através do exercício hermenêutico.

Os preceitos constitucionais regem todo o ordenamento jurídico existente, posto ser um sistema de normas complexo, que deve ser entendido em conjunto. As figuras previstas com proteção integral pela legislação vigente precisam ter seus direitos efetivados com prioridade, empregando toda a sistematicidade do ordenamento jurídico para que seus direitos sejam tutelados de forma efetiva.

Desse modo, entende-se como possível a aplicação análoga da lei 12.318 de 2010 para tutelar o direito de convivência familiar do idoso, efetivando o princípio da dignidade da pessoa humana e da proteção especial e integral previstas na Constituição Federal e no Estatuto do Idoso, podendo ser considerado vítima de alienação parental e necessitando de tutela para a garantia de seus direitos.

\section{REFERÊNCIAS}

ANDRIGHI, Fátima Nancy. 0 acesso do idoso ao judiciário. p.1. Disponível em: <http://www.egov.ufsc.br/portal/sites/default/files/anexos/15358-15359-1-PB.pdf.>. Acesso em: 18 out. 2015.

AQUINO, Luseni Maria Cordeiro; MELLO, Simone Gueresi; SILVA, Enid Rocha Andrade. Os abrigos para crianças e adolescentes e a promoção do direito à convivência familiar. Disponível em: <http:// repositorio.ipea.gov.br/bitstream/11058/3050/10/Livro_cap.\%208>. Acesso em: 9 mai. 2016. 
BASTOS, Maria Isis de Araújo; CAMPOS, Carolinne Pinheiro. 0 idoso como vítima de alienação parental: nova possibilidade interpretativa do art. $2^{\circ}$ da Lei 12.318 de 2010. Disponível em: < http://www.publicadireito.com.br/artigos/?cod=fa873e7f272a69e1>. Acesso em: 29 de mai. 2016.

BALDONI, A.O.; PEREIRA, L.R.L. O impacto do envelhecimento populacional brasileiro para o sistema de saúde sob a óptica da farmacoepidemologia: uma revisão narrativa. Disponível em: <http://www.unifal-mg. edu.br/cefal/sites/default/files/Baldoni,\%20Pereira,\%202011.pdf>. Acesso em: 11 out. 2015.

BARROSO, Luís Roberto. Interpretação e aplicação da constituição. 7. ed. São Paulo: Saraiva, 2009.

BRASIL. Constituição da República Federativa do Brasil de 1988. Disponível em: <http://www.planalto.gov.br/ccivil_03/constituicao/ ConstituicaoCompilado.htm>.Acesso em: 11 out. 2015.

BRASIL. Decreto-Lei no 4657, de 4 de setembro de 1942. Lei de Introdução às normas do Direito Brasileiro. Disponível em: <http://www. planalto.gov.br/ccivil_03/decreto-lei/Del4657.htm>. Acesso em: 11 out. 2015.

BRASIL. Lei 10.741 de $1^{\circ}$ de outubro de 2003. Estatuto do Idoso. Disponível em: <http://www.planalto.gov.br/ccivil_03/leis/2003/L10.741. htm>. Acesso em: 11 out. 2015.

BRASIL. Lei 12.318 de 26 de agosto de 2010. Disponível em: <http:// www.planalto.gov.br/ccivil_03/_ato2007-2010/2010/lei/l12318.htm>. Acesso em: 29 de mai. 2016.

BRASIL. Lei 8.069 de 13 de julho de 1990. Estatuto da criança e do adolescente. Disponível em: <http://www.planalto.gov.br/ccivil_03/ leis/L8069.htm>. Acesso em: 22 abr. 2016.

BRASIL. Lei 8.078 de 11 de setembro de 1990. Disponível em: <http:// www.planalto.gov.br/ccivil_03/leis/L8078.htm>. Acesso em: 17 mai. 2016.

BRASIL. Lei 8842 de 4 de janeiro de 1994. Disponível em: http://www. planalto.gov.br/ccivil_03/leis/L8842.htm<http://www.planalto.gov.br/ ccivil_03/leis/L8842.htm>. Acesso em: 11 out. 2015.

BRASIL. Presidência da República: Secretaria de Direitos Humanos. Dados sobre o envelhecimento no Brasil. Disponível em:<http://www. 
sdh.gov.br/assuntos/pessoa-idosa/dados-estatisticos/DadossobreoenvelhecimentonoBrasil.pdf>. Acesso em: 11 out. 2015.

CAMARANO, Ana Amélia. et al. Como vai o idoso brasileiro. Disponível em: <http://repositorio.ipea.gov.br/bitstream/11058/2810/1/td_0681. pdf>. Acesso em: 11 out. 2015.

CANOTILHO, José Joaquim Gomes. Direito constitucional e teoria da constituição. 7. ed. Coimbra: Almedina, 2003.

CARVALHO, Kildare Gonçalves. Direito constitucional. 17. ed. Belo Horizonte: Del Rey, 2011.

COSTA, Eliane Romeiro. Oestatuto do idoso no sistema de proteção social. Disponível em: <http://www.fema.com.br/ direito/debora/ antigos/sociologia/idoso/estatutoidoso_eliane.pdf>. http://www.fema. com.br/ direito/debora/sociologia/estatuto_idoso/estatuto_idoso_sistema_protecao_social.pdfAcesso em: 18 out. 2015.

DIAS, Maria Berenice (Coord.). Incesto e alienação parental. 3. ed. São Paulo: Revista dos Tribunais, 2013.

DIAS, Maria Berenice. Manual de direito das famílias. 7. ed. São Paulo: Editora Revista dos Tribunais, 2010.

DINIZ, Maria Helena. Compêndio de introdução à ciência do direito. 17. ed. São Paulo: Saraiva, 2010.

ESTADO DO RIO GRANDE DO SUL. Tribunal de Justiça. Agravo de instrumento no 70065085839, Sétima Câmara Cível. Relator Des.Jorge Luis Dall'Agnol. Julgado em 26 de agosto de 2015.

ESTADO DO RIO GRANDE DO SUL. Tribunal de Justiça. Agravo de instrumento no 70067690586, Sétima Câmara Cível. Relator Des. ${ }^{a}$ Sandra Brisolara Medeiros. Julgado em 16 de março de 2016.

ESTADO DO RIO GRANDE DO SUL. Tribunal de Justiça.Apelação cível de no 70067792564, Oitava Câmara Cível.Relator: Luiz Felipe Brasil Santos. Julgado em 3 de março de 2016.

ESTADO DO RIO GRANDE DOS SUL. Tribunal de Justiça. Agravo de instrumento no 70067827527,Sétima Câmara Cível. Relator: Sergio Fernando Silva de Vasconcellos Chaves. Julgado em 16 de março de 2016.

FALEIROS, Vicente de Paula. Cidadania e direitos da pessoa idosa. Disponível em:<http://repositorio.unb.br/bitstream/10482/8353/1/ ARTIGO_CidadaniaDireitosPessoaIdosa.pdf>. Acesso em: 11 out. 2015. 
FARIAS, Cristiano Chaves de; ROSENVALD, Nelson. Direito das famílias. 3. ed. Rio de Janeiro: Lumen Juis, 2011.

FERNANDES, Maria Terezinha de Oliveira; SOARES, Sonia Maria. 0 desenvolvimento de políticas públicas de atenção ao idoso no Brasil. Disponível em: <http://www.revistas.usp.br/reeusp/article/ view/52841/0>. Acesso em: 18 out. 2015.

FIORELLI, José Osmir; MANGINI, Rosana Cathya Ragazzoni. Psicologia jurídica. 2. ed. São Paulo: Atlas, 2010.

GARDNER, Richard. O DSM-IV tem equivalente para o diagnóstico da síndrome da alienação parental(SAP)? Disponível em: <http://www.alienacaoparental.com.br/textos-sobre-sap-1/o-dsm-iv-tem-equivalente>. Acesso em: 29 out. 2015

KEINERT, Tania Margarete Mezzamo; ROSA, Tereza Etsuko da Costa. Direitos humanos, envelhecimento ativo e saúde da pessoa idosa: marco legal e institucional. Disponível em: http://periodicos.ses.sp.bvs.br/ scielo.php?script=sci_arttext\&pid=S1518-18122009000200002\&lng= pt\&nrm=iso>. Acesso em 11 out. 2015.

KELSEN, Hans. Teoria pura do direito. 8. ed. São Paulo: WMF Martins Fontes, 2009.

LOBO, Paulo. Direito civil: famílias. 3. ed. São Paulo: Saraiva, 2010.

MARQUES, Claudia Lima; MIRAGEM, Bruno. 0 novo direito privado e a proteção dos vulneráveis. 2. ed. São Paulo: Revista dos Tribunais, 2014.

MAXIMILIANO, Carlos. Hermenêutica e aplicação do direito. 19. ed. Rio de Janeiro: Forense, 2010.

MENDES, Gilmar Ferreira; COELHO, Inocêncio Mártires; BRANCO, Paulo Gustavo Gonet. Curso de direito constitucional. 5. ed. São Paulo: Saraiva, 2010.

PADILHA, Elisangela. A Constitucionalização do direito privado e a roteçao dos direitos fundamentais nos novos arranjos familiares. Direitos Fundamentais \& Justiça. Pontifica Universidade Católica do Rio Grande do Sul. N. 33(out/dez 2015) Porto Alegre: HS Editora, 2015.

PODER JUDICIÁRIO DO ESTADO DO MATO GROSSO. Cartilha alienação parental. Disponível em: <http://www.tjmt.jus.br/intranet.arq/downloads/Imprensa/NoticiaImprensa/file/2014/04\%20-\%20Abril/25\%20-\%20Cartilha\%20-\%20Aliena\%C3\%A7\%C3\%A3o.pdf>. Acesso em: 15 ago. 2015. 
PROGRAMA DAS NAÇÕES UNIDAS PARA O DESENVOLVIMENTO. Índice de desenvolvimento humano 2013. Disponível em: <http://www.pnud. org.br/arquivos/rdh-2013.pdf>. Acesso em: 11 out. 2015.

RAMOS, Paulo Roberto Barbosa. A velhice na constituição. Disponível em: <https://periodicos.ufsc.br/index.php/sequencia/article/download/15513/14069>. Acesso em: 11 out. 2015.

RAMOS, Paulo Roberto Barbosa. Curso de direito do idoso. São Paulo: Saraiva, 2014.

SARLET, Ingo Wolfgang. 0 conceito de Direitos Fundamentais na Constituição Federal de 1988. Disponível em: <http://www.conjur.com. br/2015-fev-27/direitos-fundamentais-conceito-direitos-fundamentais-constituicao-federal-1988>. Acesso em: 11 de out. 2015.

SARLET, Ingo Wolgang. A eficácia dos direitos fundamentais: uma teoria geral dos direitos fundamentais na perspectiva constitucional. 10. ed. Porto Alegre: Livraria do Advogado, 2010.

SECRETARIA DE DIREITOS HUMANOS DA PRESIDENCIA DA REPÚBLICA. Participação Social. Conselho nacional dos direitos do idoso (CNDI). Disponível em: <http://www.sdh.gov.br/sobre/participacao-social/ conselho-nacional-dos-direitos-do-Idoso-CNDI>. Acesso em: 29 out 2015.

SILVA, Nilson Tadeu Reis Campos. Direito do Idoso:tutela jurídica constitucional. Curitiba: Juruá, 2012.

TRINDADE, Jorge. Manual de psicologia jurídica para operadores do direito. 4. ed. Porto Alegre: Livraria do Advogado, 2010.

VILAS BOAS, Marco Antônio. Estatuto do idoso comentado. 5. ed. Rio de Janeiro: Forense, 2015. 